\title{
14. TERTIARY AND QUATERNARY CALCAREOUS NANNOPLANKTON BIOSTRATIGRAPHY OFF PERU (ODP LEG 112) ${ }^{1}$
}

\author{
Erlend Martini ${ }^{2}$
}

\begin{abstract}
Positions of all cores recovered during Ocean Drilling Program (ODP) Leg 112 off Peru are shown in the standard calcareous nannoplankton zonation. Stratigraphic and regional occurrences and preservation of calcareous nannoplankton are discussed for all sites, and fossil lists are presented for selected samples. Late Miocene to Holocene nannoplankton assemblages in the upwelling systems off Peru and scattered blooms, especially of Gephyrocapsa species and Helicosphaera carteri, are described. Scyphosphaera assemblages found in late Miocene Zone NN9 (Discoaster hamatus Zone) at Site 684 are compared with similar assemblages from Gabon on the west coast of Africa. Remarkable subsidence is indicated by early and middle Eocene nearshore and shallow-water nannoplankton assemblages for Sites 682,683 , and 688 . Besides several local hiatuses, major regional hiatuses were noted at Site 682 (upper Eocene, uppermost middle Eocene, and part of the lower and middle Oligocene missing), Site 683 (uppermost middle Eocene to lower part of the middle Miocene missing), and Site 688 (part of the middle Eocene, uppermost middle Eocene to upper Oligocene, and parts of the lower and middle Miocene missing).
\end{abstract}

\section{INTRODUCTION}

During ODP Leg 112, 10 sites (679 through 688) were occupied and 27 holes drilled in the forearc basins and continental slope of the convergent margin off Peru (Fig. 1). The main objectives of Leg 112 were (1) investigation of the paleoceanographic conditions of the upper-slope basin deposits in connection with fluctuations of the upwelling systems, (2) reconstruction of the vertical movement of the continental margin, (3) study of the nature and age of the transition zone that lies between the lower-slope accretionary complex and the metamorphic basement, and (4) evaluation of the geochemical processes connected with the upwelling system and diagenesis in organic carbon-rich sediments. Most sites were aligned along two transects at $9^{\circ} \mathrm{S}$ (Sites 684, 683, and 685 ) and near $11^{\circ} \mathrm{S}$ (Sites 681, 680, 679, 688, and 682). Two additional sites were occupied in the Pisco Basin (Sites 686 and 687).

All holes yielded calcareous nannoplankton, although barren intervals occurred frequently in the late Miocene to Holocene sequences in the upwelling areas. Paleogene sediments were recovered only in the deeper Sites 682,683 , and 688 (Table 1). The observed calcareous nannoplankton assemblages are discussed below, and fossil lists of selected samples for all sites are represented in Tables 2 through 8 and Tables 10 through 12 .

\section{CALCAREOUS NANNOPLANKTON ZONATION}

For Tertiary and Quaternary sediments. the standard calcareous nannoplankton zonation (Martini, 1971; Martini and Müller, 1986) is used. However, because sphenoliths are poorly preserved or missing in the nannoplankton assemblages of middle to late Oligocene age at Site 682 , the following deviation has been necessary:

\footnotetext{
${ }^{1}$ Suess, E., von Huene, R., et al., 1990. Proc, ODP, Sci. Results, 112: College Station, TX (Ocean Drilling Program).

2 Geologisch-Paläontologisches Institut der Universität, Senckenberg-Anlage 32-34, D-6000 Frankfurt am Main, Federal Republic of Germany.

${ }^{3}$ Superscript asterisk indicates that top marker has been changed, subscript asterisk, that base marker has been changed.
}

\section{NP24/NP25 *3 \\ (combined Sphenolithus distentus/S. ciperoensis Zone) ${ }^{3}$}

Substitute definition. Interval from the first occurrence of Cyclicargolithus abisectus (Müller) to the last occurrences of Zygrhablithus bijugatus (Deflandre) and Dictyococcites dictyodus (Deflandre).

Remarks. Similar difficulties exist in high latitudes, where sphenoliths are frequently missing in the middle and late Oligocene interval, and Helicosphaera recta (Haq) is not represented in most of the calcareous nannoplankton assemblages. In these areas, $C$. abisectus and $Z$. bijugatus are taken as substitute species (Müller, 1976, 1979; Martini, 1979, 1986).

Correlations between the low-latitude coccolith zonation of Okada and Bukry (1980) and standard nannoplankton zonation are outlined in Tables 4 and 5 of Martini and Müller's study (1986) of current Tertiary and Quaternary calcareous nannoplankton stratigraphy.

Data for calibration of Tertiary and Quaternary zonal boundaries to absolute ages were taken from Backman and Shackleton (1983), Berggren et al. (1985), and Martini (1986). Concerning the misleading version of the Oligocene in Berggren et al. (1985), the reader is referred to Martini et al.'s discussion (1986) of the threefold subdivision of the Oligocene.

\section{SITE SUMMARIES}

$$
\begin{gathered}
\text { Site } 679\left(11^{\circ} 03.52^{\prime} \mathrm{S}, 7^{\circ} 15.92^{\prime} \mathrm{W}\right. \text {; } \\
\text { water depth, } 439.5 \mathrm{~m})
\end{gathered}
$$

Five holes were drilled at Site 679 , located on the outer continental shelf of Peru, to sample sediments beneath a modern upwelling plume. The youngest sediments are present in Cores 112-679C-1H and -679D-1H, where a Gephyrocapsa spp./Helicosphaera carteri Assemblage also contains Emiliania huxleyi, indicating the Holocene calcareous nannoplankton Zone NN21 (Emiliania huxleyi Zone), which is younger than $0.275 \mathrm{Ma}$.

The Gephyrocapsa spp./Helicosphaera carteri Assemblage was found in Samples 112-679A-1H, CC, -679B-1H, CC, -2H, $\mathrm{CC},-3 \mathrm{H}, \mathrm{CC}$, and in Core 112-679D-2H. Because E. huxleyi could not be found, these samples are placed in the late Pleistocene nannoplankton Zone NN20 (Gephyrocapsa oce- 


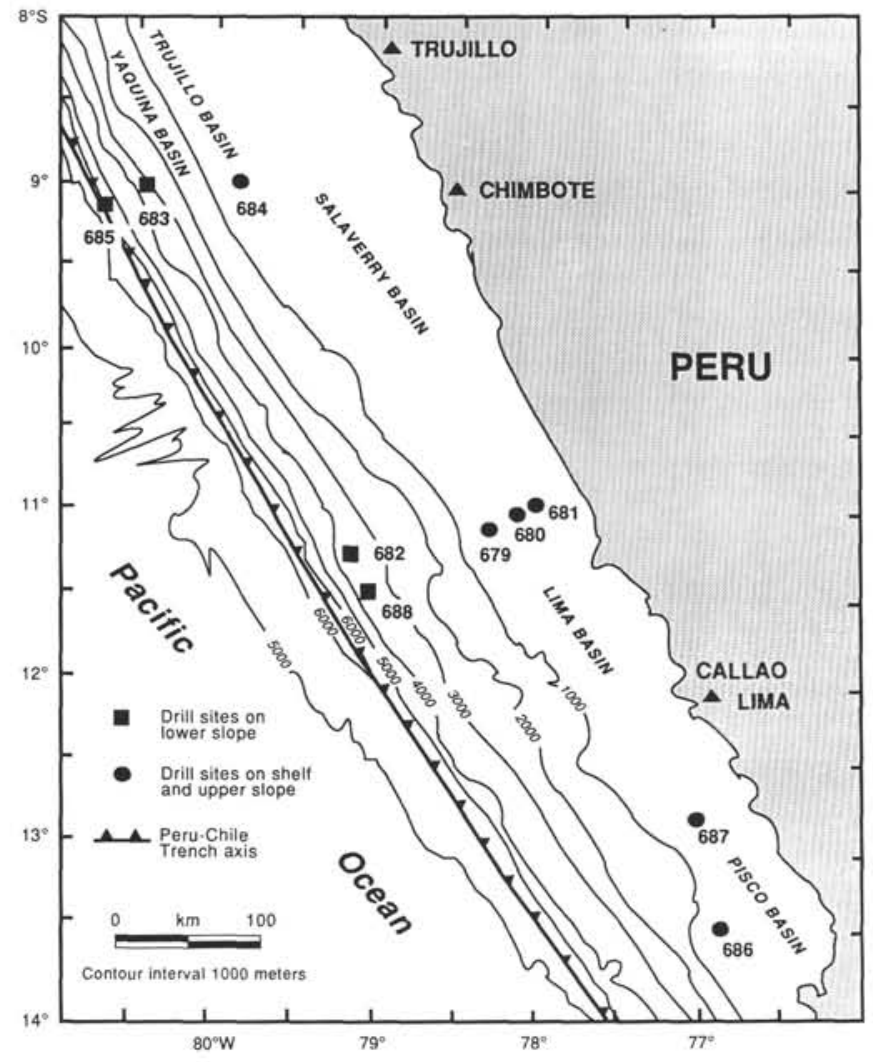

Figure 1. Location of sites drilled during Leg 112 in the eastern South Pacific off Peru. Contours in meters.

anica Zone), above the last occurrence of Pseudoemiliania lacunosa $(0.47 \mathrm{Ma})$. An assemblage dominated by Coccolithus pelagicus is present in Samples 112-679B-4H, CC, $-679 \mathrm{C}-2 \mathrm{H}, \mathrm{CC},-4 \mathrm{H}, \mathrm{CC},-5 \mathrm{H}, \mathrm{CC}$, and $-679 \mathrm{D}-4 \mathrm{H}, \mathrm{CC}$, indicating cold-water conditions. A few Gephyrocapsa specimens, Cyclococcolithus leptoporus, and rare Helicosphaera sellii also occur in some of these samples. As Pseudoemiliania lacunosa probably is missing in this particular assemblage, these samples are placed only tentatively in nannoplankton Zone NN19 (Pseudoemiliania lacunosa Zone).

Several samples between the Coccolithus pelagicus Assemblage and the underlying Reticulofenestra pseudoumbilica/Coccolithus pelagicus Assemblage were barren. These included Samples 112-679D-5H, CC, $-6 \mathrm{H}, \mathrm{CC}$, and $-7 \mathrm{H}$, $\mathrm{CC}$, as well as Samples 112-679C-3H, CC, and -6H, CC. Cores $112-679 \mathrm{D}-9 \mathrm{H},-10 \mathrm{H},-12 \mathrm{H}$ to $-18 \mathrm{X}$, and $-20 \mathrm{X}$ within the Reticulofenestra pseudoumbilica/Coccolithus pelagicus Assemblage also were barren. The $R$. pseudoumbilica/C. pelagicus Assemblage was observed in Samples 112-679B$8 \mathrm{H}, \mathrm{CC},-9 \mathrm{H}, \mathrm{CC},-12 \mathrm{H}, \mathrm{CC},-13 \mathrm{H}, \mathrm{CC}, 112-679 \mathrm{C}-7 \mathrm{H}, \mathrm{CC}$, $-8 \mathrm{H}, \mathrm{CC}$, and in Cores 112-679D-8H, $-11 \mathrm{H}$, and Sample $112-679 \mathrm{D}-12 \mathrm{H}-1,61-62 \mathrm{~cm}$. This assemblage is not younger than $3.5 \mathrm{Ma}$ because the last occurrence of $R$. pseudoumbilica marks the top of calcareous nannoplankton Zone NN15 (Reticulofenestra pseudoumbilica Zone). These samples are tentatively placed in the early Pliocene nannoplankton Zone NN15, although owing to the low diversity they may be older, indicating a possible hiatus just above this level. In Core 112-679D-19X, a sudden occurrence of well-preserved $R$. pseudoumbilica, together with Sphenolithus abies, Cyclococcolithus leptoporus, and $C$. pelagicus in an otherwise barren sequence between Cores 112-679D-12H and -679D$27 \mathrm{X}$ again was noted (Table 2).
Samples from Hole 679E ( 245.3 to $359.3 \mathrm{mbsf}$ ) are barren of calcareous nannoplankton, with the exception of some levels within Cores 112-679E-11X and $-12 \mathrm{X}$. This meager assemblage contains some discoasters besides Reticulofenestra pseudoumblica, Coccolithus pelagicus, and Helicosphaera carteri. These include Discoaster exilis and Discoaster variabilis. In Sample 112-679E-12X, CC, Cyclicargolithus cf. floridanus was observed, and this assemblage is tentatively placed in the middle Miocene calcareous nannoplankton Zone NN6 (Discoaster exilis Zone).

\section{Site $680\left(11^{\circ} 03.90^{\prime} \mathrm{S}, 78^{\circ} 04.67^{\prime} \mathrm{W}\right.$; water depth, $252.5 \mathrm{~m}$ )}

Three holes were drilled at Site 680 , which is centered on an east-west transect of three sites across the coastal upwelling deposits off Peru. The deepest hole (680B) terminated at 195.5 mbsf.

In Hole $680 \mathrm{~A}$, calcareous nannoplankton was found only in the upper five cores in rather monotonous assemblages at various levels. Assemblages in Cores $112-680 \mathrm{~A}-1 \mathrm{H}$ to $-4 \mathrm{H}$ include Gephyrocapsa oceanica, Gephyrocapsa aperta, Helicosphaera carteri, Cyclococcolithus leptoporus, and others (Table 3), and belong to nannoplankton Zone NN20 (Gephyrocapsa oceanica Zone). However, Sample 112-680A-1H-4, $98-99 \mathrm{~cm}$, in which some specimens of Emiliania huxleyi were noted, should be placed in nannoplankton Zone NN21 (Emiliania huxleyi Zone). In Sample 112-680A-5H-4, 22-23 cm, a few specimens of Pseudoemiliania lacunosa were found, indicating that this level is not younger than nannoplankton Zone NN19 (Pseudoemiliania lacunosa Zone). Cores 112$680 \mathrm{~A}-6 \mathrm{H}$ to $-10 \mathrm{H}$ are barren of calcareous nannoplankton.

A similar distribution pattern was found in Hole $680 \mathrm{~B}$. Quaternary calcareous nannoplankton is present in the upper five cores. The lowest occurrence of nannoplankton was noted in Sample 112-680B-7H, CC, but in this case, may represent downhole contamination. All other cores down to the terminal Core 112-680B-22X are barren of calcareous nannoplankton. A mass occurrence of calcareous nannoplankton was found in a pale, 4-mm-thick layer at 112-680B-2H-1, $105-106 \mathrm{~cm}$, and represents a bloom of Helicosphaera carteri and Gephyrocapsa oceanica, of which coccospheres also are preserved. Because rare Emiliania huxleyi also were noted, this assemblage still belongs to nannoplankton Zone NN21 (Emiliania huxleyi Zone) and is documented in Pl. 1, Figs. 1 through 3.

Dolomite rhombs are seen frequently in several samples from both holes, and a relationship between these and the abundance of calcareous nannoplankton was noted. With an increase of dolomite rhombs, nannoplankton assemblages become scarce and finally disappear (Table 3). Core-catcher Samples $112-680 \mathrm{C}-1 \mathrm{H}$ to $-4 \mathrm{H}$ were barren of calcareous nannoplankton, with Sample 112-680C-3H-CC showing abundant dolomite rhombs.

\section{Site $681\left(10^{\circ} 58.60^{\prime} \mathrm{S}, 77^{\circ} 57.46^{\prime} \mathrm{W}\right.$; water depth, $150.5 \mathrm{~m}$ )}

Three holes were drilled at Site 681 , which is the most landward site of a transect across the coastal upwelling system off Peru at $11^{\circ} \mathrm{S}$. Hole $681 \mathrm{~A}$ (the deepest hole) was terminated at 187.0 mbsf.

Calcareous nannoplankton was found in meager assemblages at various levels in the Quaternary part of Site 681. The most common species observed are Gephyrocapsa aperta, Gephyrocapsa oceanica, Helicosphaera carteri, and Cyclococcolithus leptoporus. The cold-water species Coccolithus pelagicus was observed in only a few samples (Table 4). This 
Table 1. Calcareous nannoplankton stratigraphy of Sites 679 to 688.

\begin{tabular}{|c|c|c|c|c|c|c|c|c|c|c|c|c|c|c|c|c|c|c|c|c|c|c|c|}
\hline & & 6798 & $679 \mathrm{C}$ & 6790 & 679E & $680 \mathrm{~A}$ & 6808 & $681 \mathrm{~A}$ & 6818 & $681 C$ & $682 \mathrm{~A}$ & $683 \mathrm{~A}$ & 6838 & $684 \mathrm{~A}$ & 6848 & $684 \mathrm{C}$ & $685 \mathrm{~A}$ & $686 \mathrm{~A}$ & 6868 & $687 \mathrm{~A}$ & 6878 & $688 \mathrm{~A}$ & $688 \mathrm{E}$ \\
\hline \multirow{3}{*}{ Quaternary } & NN 21 & 1 & 1 & 1 & & 1 & $1-2$ & 1 & 1 & 1 & 1 & 1 & & & & & & & & & & 1 & \\
\hline & NN 20 & $1-3$ & 1 & 2 & & $1-4$ & $2-4$ & $1-7$ & $1-7$ & $1-8$ & \begin{tabular}{|l|l|}
$1-3$ \\
\end{tabular} & $1-7$ & & $1-2$ & 1 & & $3-7$ & 8 & & $6-7$ & & $1-4$ & \\
\hline & NN 19 & 4 & $2-5$ & $3-5$ & & 5 & 5 & $9-14$ & $9-15$ & 10 & & (14-9) & & & & & $8-21$ & \begin{tabular}{|l|}
10,12 \\
$16-22$ \\
\end{tabular} & 25 & \begin{tabular}{|c|}
174 \\
$17-22$ \\
\end{tabular} & \begin{tabular}{|c|}
9,16 \\
$19-22$ \\
\end{tabular} & $5-22$ & \\
\hline \multirow{3}{*}{$\begin{array}{l}\text { Upper } \\
\text { Pliocene }\end{array}$} & NN 18 & & & & & & & & & & \multirow{3}{*}{7} & 19 & & & & & & & & & & & \\
\hline & NN 17 & & & & & & & & & & & & & & & & & & & & & & \\
\hline & NN 16 & & & & & & & & & & & & & $4-6$ & $(3-4)$ & 4.6 & & & & & & & \\
\hline \multirow{4}{*}{$\begin{array}{l}\text { Lower } \\
\text { Pliocene }\end{array}$} & NN 15 & $8-13$ & $7-8$ & 8,11 & & & & (19?) & & & 8 & & & & & & & & & & & & \\
\hline & NN 14 & & & \multirow{2}{*}{12,19} & & & & & & & & & & & & & & & & & & & \\
\hline & NN 13 & & & & & & & & & & & & & & & & & & & & & & \\
\hline & NN 12 & & & & & & & & & & & & & & & & & & & & & & \\
\hline \multirow{3}{*}{$\begin{array}{l}\text { Upper } \\
\text { Miocene }\end{array}$} & N N 11 & & & & & & & & & & & & & & & & $23-25$ & & & & & & \\
\hline & NN 10 & & & & & & & & & & & & & & & & \begin{tabular}{|l|}
26 \\
38 \\
\end{tabular} & & & & & & \\
\hline & $\mathrm{NN} 9$ & & & & & & & & & & \multirow{4}{*}{$15-29$} & & & $7-14$ & & $8-13$ & & & & & & & \\
\hline \multirow{4}{*}{$\begin{array}{l}\text { Middle } \\
\text { Miocene }\end{array}$} & N N 8 & & & & & & & & & & & 30 & & & & & & & & & & & \\
\hline & NN 7 & & & & & & & & & & & 27 & & & & & & & & & & & \\
\hline & NN 6 & & & & $11-13$ & & & & & & & \begin{tabular}{c|}
$28-33$ \\
39 \\
\end{tabular} & & & & & & & & & & & \begin{tabular}{|l|}
$12-16$ \\
$(17-21)$ \\
\end{tabular} \\
\hline & NN 5 & & & & & & & & & & $32-33 / 4$ & $40-45$ & $1-5$ & & & & & & & & & & \\
\hline \multirow{4}{*}{$\begin{array}{l}\text { Lower } \\
\text { Miocene }\end{array}$} & NN 4 & & & & & & & & & & 34 & & & & & & & & & & & & \\
\hline & NN 3 & & & & & & & & & & 35 & & 国 & & & & & & & & & & \\
\hline & NN 2 & & & & & & & & & & 35 & & |f & & & & & & & & & & \multirow{2}{*}{$22-25$} \\
\hline & NN 1 & & & & & & & & & & 36 & & & & & & & & & & & & \\
\hline \multirow{2}{*}{$\begin{array}{l}\text { Upper } \\
\text { Oligocene }\end{array}$} & NP25 & & & & & & & & & & \multirow{2}{*}{$37-41$} & & & & & & & & & & & & \\
\hline & NP 24 & & & & & & & & & & & & & & & & & & & & & & \\
\hline $\begin{array}{l}\text { Middle } \\
\text { Oligocene }\end{array}$ & NP 23 & & & & & & & & & & 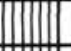 & & & & & & & & & & & & \\
\hline \multirow{2}{*}{$\begin{array}{l}\text { Lower } \\
\text { Oligocene }\end{array}$} & NP22 & & & & & & & & & & 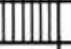 & & & & & & & & & & & & \\
\hline & NP21 & & & & & & & & & & 44 & & $\|$ & & & & & & & & & & \\
\hline \multirow{2}{*}{$\begin{array}{l}\text { Upper } \\
\text { Eocene }\end{array}$} & NP19/20 & & & & & & & & & & $\|$ & & $\|$ & & & & & & & & & & \\
\hline & NP 18 & & & & & & & & & & |n & & ||ा|| & & & & & & & & & & 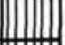 \\
\hline \multirow{4}{*}{$\begin{array}{l}\text { Middle } \\
\text { Eocene }\end{array}$} & NP 17 & & & & & & & & & & ||س & & 7 & & & & & & & & & & |l|| \\
\hline & NP 16 & & & & & & & & & & 45- 48 & & $7-9$ & & & & & & & & & & $27-36$ \\
\hline & NP 15 & & & & & & & & & & & & & & & & & & & & & & $\|$ \\
\hline & NP 16 & & & & & & & & & & & & & & & & & & & & & & 36 \\
\hline Lower Eocene & NP 13 & & & & & & & & & & & & & & & & & & & & & & $36-45$ \\
\hline
\end{tabular}

Note: Numbers refer to cores. Hiatuses based on calcareous nannoplankton striped. Zones = standard nannoplankton zones.

species is much more common at the offshore Site 679 than at either Sites 680 or 681 .

Minor blooms of Gephyrocapsa species, including wellpreserved coccospheres, were found in Samples 112-681A$1 \mathrm{H}-4,125 \mathrm{~cm},-681 \mathrm{~A}-4 \mathrm{H}-3,117 \mathrm{~cm}$, and $-681 \mathrm{~B}-4 \mathrm{H}-2,98-99$ $\mathrm{cm}$ (Pl. 1, Fig. 4). Calcareous nannoplankton is present only in low diversity and in low individual numbers and is further diminished by the carbonate uptake during dolomite formation, which was already noted at Site 680 .

Stratigraphically, Cores $112-681 \mathrm{~A}-1 \mathrm{H}$ to $-14 \mathrm{X}$, Cores 112 $681 \mathrm{~B}-1 \mathrm{H}$ to $-15 \mathrm{X}$, and all 10 cores of Hole $681 \mathrm{C}$ can be placed in the Quaternary. In Sample 112-681A-1H-1, 89-90 cm, rare Emiliania huxleyi were noted, indicating that this level belongs to nannoplankton Zone NN21 (Emiliania huxleyi Zone). The remaining samples from Core $112-681 \mathrm{~A}-1 \mathrm{H}$ down to the upper part of Core 112-681-7H can be placed in nannoplankton Zone NN20 (Gephyrocapsa oceanica Zone). Samples 112-681A-9H, CC, -681A-10H-3, 50-51 cm, -681B-9H, CC, and -681B-10H, CC, contain Pseudoemiliania lacunosa, and thus are no younger than nannoplankton Zone NN19 (Pseudo- emiliania lacunosa Zone). Cyclococcolithus macintyrei was found in Sample 112-681B-14X, CC, indicating that this level is no younger than the lowest part of Zone NN19 (= top of Subzone NN19a = last occurrence of Cyclococcolithus macintyrei, $1.45 \mathrm{Ma}$ ). This seems in good agreement with the silicoflagellate data for this hole (Martini, this volume) because the earliest occurrence of the silicoflagellate Distephanus bioctonarius bioctonarius was noted in Sample 112681B-13X, CC. Several intervals barren of calcareous nannoplankton were found in all holes, including Cores 112-681A$15 \mathrm{X}$ to $-18 \mathrm{X}$ and $-20 \mathrm{X}$ (Table 4 ).

Near the bottom of Hole $681 \mathrm{~A}$, rare displaced Reticulofenestra pseudoumbilica, Dictyococcites dictyodus, and $C y$ clicargolithus floridanus were observed in an otherwise Quaternary nannoplankton assemblage in Sample 112-681A-19X, CC. However, the presence of Reticulofenestra pseudoumbilica also may indicate that this level represents the early Pliocene with displaced Eocene or Oligocene nannoplankton and with downhole contamination from the Quaternary resulting from drilling difficulties. 
Table 2. Distribution of calcareous nannoplankton in selected samples from Holes 679D and 679E and indication of standard nannoplankton zones.

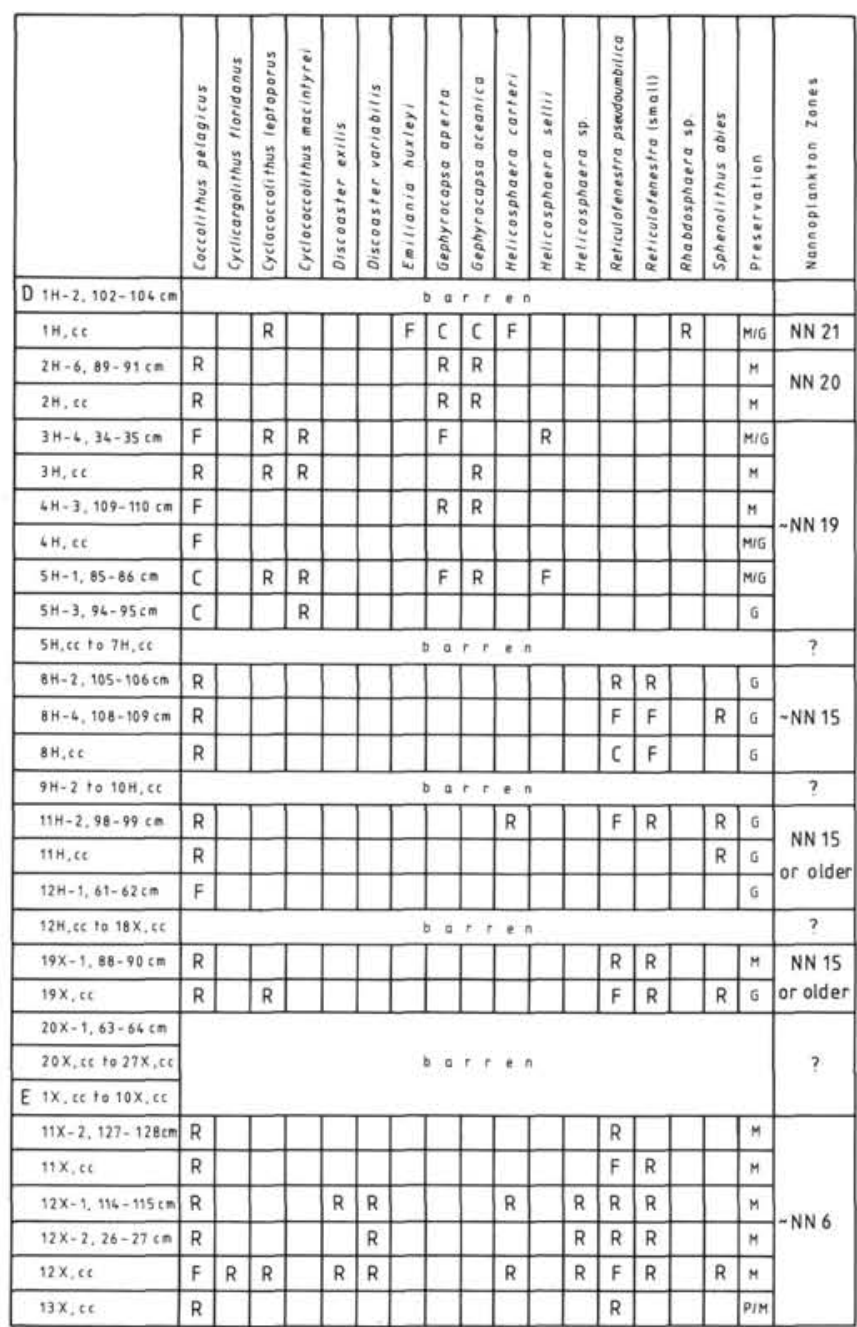

Note: $\mathrm{R}=$ rare, $\mathrm{F}=$ few, $\mathrm{C}=$ common, $\mathrm{A}=$ abundant. Preservation: $\mathrm{P}=$ poor, $\mathrm{M}=$ moderate, $\mathrm{G}=$ good.

\section{Site $682\left(11^{\circ} 15.99^{\prime} \mathrm{S}, 79^{\circ} 03.73^{\prime} \mathrm{W}\right.$; water depth, $3788.5 \mathrm{~m}$ )}

One hole was drilled at this site to establish the history of vertical tectonism and to sample distal material from upwelling on the shelf area. Hole $682 \mathrm{~A}$ terminated at $436.7 \mathrm{mbsf}$ in middle Eocene sediments.

Quaternary calcareous nannoplankton was found in rather monotonous assemblages in Cores $112-682 \mathrm{~A}-1 \mathrm{H}$ to $-3 \mathrm{H}$. Species identified include Emiliania huxleyi in Sample 112-682A$1 \mathrm{H}-2$, 95-96 cm, indicating the presence of nannoplankton Zone NN-21 (Emiliania huxleyi Zone) in the upper part of Core 112-682A-1H. The nannoplankton assemblages of the remaining part of this interval are dominated by Gephyrocapsa oceanica and Gephyrocapsa aperta, as well as Cyclococcolithus leptoporus (in Sample 112-682A-2H-6, 62-63 $\mathrm{cm}$ ), whereas Helicosphaera carteri and Coccolithus pelagicus are rare. Because Pseudoemiliania lacunosa is missing, the above interval represents nannoplankton Zone NN20 (Gephyrocapsa oceanica Zone), which is confirmed by crosscorrelation with silicoflagellates.

Cores $112-682 \mathrm{~A}-4 \mathrm{H}$ to $-6 \mathrm{H}$ and $-9 \mathrm{X}$ to $-14 \mathrm{X}$ are barren of calcareous nannoplankton.
Table 3. Distribution of calcareous nannoplankton in selected samples from Holes $680 \mathrm{~A}$ and $680 \mathrm{~B}$ and indication of standard nannoplankton zones.

\begin{tabular}{|c|c|c|c|c|c|c|c|c|c|c|c|c|}
\hline & 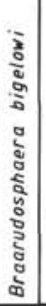 & 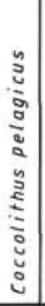 & 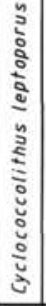 & 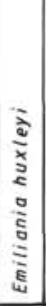 & 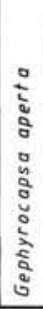 & 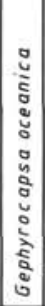 & $\begin{array}{c} \\
\vdots \\
\vdots \\
\vdots \\
\vdots \\
\vdots \\
\vdots \\
\vdots \\
\vdots \\
\vdots \\
\vdots \\
\vdots \\
\vdots \\
\vdots \\
\vdots\end{array}$ & $\begin{array}{c}0 \\
\vdots \\
\vdots \\
\vdots \\
\vdots \\
\vdots \\
0 \\
\vdots \\
\vdots \\
\vdots \\
\vdots \\
\vdots \\
\vdots \\
\vdots \\
\vdots \\
\vdots \\
0\end{array}$ & $\begin{array}{l}0 \\
\vdots \\
\vdots \\
\vdots \\
\vdots \\
\vdots \\
\vdots \\
\vdots \\
\vdots \\
\vdots \\
\vdots \\
\vdots \\
\vdots \\
\vdots \\
\vdots \\
\vdots\end{array}$ & 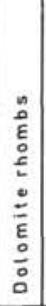 & 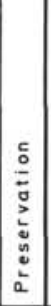 & 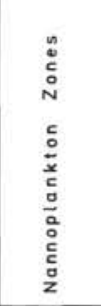 \\
\hline $1 \mathrm{H}-4,98-99 \mathrm{~cm}$ & & $\mathrm{~F}$ & $R$ & $F$ & $\mathrm{~F}$ & c & $\mathrm{R}$ & & & & $G / M$ & NN 21 \\
\hline $1 H, c c$ & $R$ & & C & & $A$ & $A$ & $C$ & & $\mathrm{R}$ & & $G$ & NN 20 \\
\hline Core $2 \mathrm{H}$ & & & & & $b a$ & $r$ & e $n$ & & & & & $?$ \\
\hline $3 \mathrm{H}=2,98-99 \mathrm{~cm}$ & & & $R$ & & $\mathrm{~F}$ & $\mathrm{R}$ & & & & & $\mathrm{G} / \mathrm{M}$ & \multirow{4}{*}{ NN 20} \\
\hline $3 \mathrm{H}, \mathrm{CC}$ & & & $\mathrm{R}$ & & A & C & C & & & & $G / M$ & \\
\hline $4 \mathrm{H}-2,119-120 \mathrm{~cm}$ & & & $\mathrm{~F}$ & & $C$ & $R$ & $R$ & & & & $\mathrm{G} / \mathrm{M}$ & \\
\hline $4 \mathrm{H}, \mathrm{CC}$ & & & & & $F$ & $R$ & & & & $>$ & $\mathrm{P} / \mathrm{M}$ & \\
\hline $5 \mathrm{H}-4,22-23 \mathrm{~cm}$ & & & $\mathrm{R}$ & & $\mathrm{F}$ & $\mathrm{F}$ & $\mathrm{R}$ & $\mathrm{R}$ & & $>$ & $P / M$ & \multirow{2}{*}{ NN 19} \\
\hline $5 \mathrm{H}, \mathrm{CC}$ & & & $\mathrm{R}$ & & $\mathrm{F}$ & $\mathrm{F}$ & $\mathrm{R}$ & & & $>$ & $\mathrm{P} / \mathrm{M}$ & \\
\hline Cores $6 \mathrm{H}$ to $10 \mathrm{H}$ & \multicolumn{11}{|c|}{ baren } & $?$ \\
\hline Cores B11H to B22X & \multicolumn{11}{|c|}{ barren } & ? \\
\hline
\end{tabular}

Note: Dolomite rhombs are not present in all samples from the interval between Cores $112-680 \mathrm{~A}-6 \mathrm{H}$ to $-10 \mathrm{H}$.

In Samples 112-682A-7X-2, 89-90 cm, and -682A-7X, CC, several Discoaster brouweri were noted in an otherwise nondiagnostic nannoplankton assemblage. Because of the unknown occurrence of index species in the late Pliocene of this region, these samples are placed in the combined interval between Zones NN16 (Discoaster surculus Zone) to NN18 (Discoaster brouweri Zone) above the last occurrence of Reticulofenestra pseudoumbilica. This species, together with Sphenolithus abies and others, is present in Sample 112$682 \mathrm{~A}-8 \mathrm{X}, 44-45 \mathrm{~cm}$, which belongs in the early Pliocene nannoplankton Zone NN5 (Reticulofenestra pseudoumbilica Zone).

Nannoplankton assemblages of Cores 112-682A-15X to $-20 \mathrm{X}$ and $-22 \mathrm{X}$ to $-29 \mathrm{X}$ are nondiagnostic. These include Discoaster variabilis in most samples, with Discoaster brouweri and Discoaster exilis present at some levels (Table 5). These samples seem to represent the upper part of the middle Miocene, but cannot be definitely assigned to certain nannoplankton zones because of low diversity and lack of index species. Dolomite rhombs were noted in varying abundance in many samples. The growth of authigenic dolomite seems to diminish calcareous nannoplankton during diagenesis, if the total carbonate content in the sediments is low. This "scavenging" of carbonate should lead to a poorly preserved, impoverished assemblage, or even result in a total loss of calcareous nannoplankton. In Cores 112-682A-30X and -31X, only gravels were recovered, and no calcareous nannoplankton data are available. In Core 112-682A-32X (bottom), Sphenolithus heteromorphus is present, and the interval between this sample and the level above Sample 112-682A-34X-1, 87-88 cm, with Helicosphaera ampliaperta placed in nannoplankton Zone NN5 (Sphenolithus heteromorphus Zone).

The lower Miocene sequence seems to be complete, and calcareous nannoplankton Zones NN4 (Helicosphaera ampliaperta Zone) to NN1 (Triquetrorhabdulus carinatus Zone) 
Table 4. Distribution of calcareous nannoplankton in selected samples from Hole 681A and indication of standard nannoplankton zones.

\begin{tabular}{|c|c|c|c|c|c|c|c|c|c|c|c|c|c|c|}
\hline & 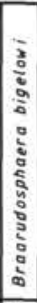 & $\begin{array}{l}n \\
5 \\
\vdots \\
\vdots \\
\vdots \\
\vdots \\
\vdots \\
\vdots \\
5 \\
\vdots \\
\vdots \\
\vdots \\
\vdots\end{array}$ & \begin{tabular}{|c|}
$n$ \\
$\vdots$ \\
$\vdots$ \\
$\vdots$ \\
$\vdots$ \\
$\vdots$ \\
$\vdots$ \\
$n$ \\
$z$ \\
$\vdots$ \\
$\vdots$ \\
$\vdots$ \\
$\vdots$ \\
$\vdots$ \\
$\vdots$ \\
$\vdots$ \\
$\vdots$ \\
$\vdots$ \\
0
\end{tabular} & 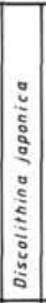 & 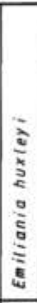 & $\begin{array}{l}0 \\
\vdots \\
\vdots \\
\vdots \\
\vdots \\
\vdots \\
\vdots \\
\vdots \\
\vdots \\
\vdots \\
\vdots \\
\vdots\end{array}$ & $\begin{array}{l}0 \\
\vdots \\
\vdots \\
\vdots \\
\vdots \\
\vdots \\
\vdots \\
\vdots \\
\vdots \\
\vdots \\
\vdots \\
\vdots \\
\vdots \\
\vdots\end{array}$ & $\begin{array}{c} \\
\vdots \\
\vdots \\
\vdots \\
\vdots \\
\vdots \\
\vdots \\
\vdots \\
\vdots \\
\vdots \\
\vdots \\
\vdots \\
\vdots\end{array}$ & \begin{tabular}{|c|} 
\\
0 \\
$\vdots$ \\
$\vdots$ \\
$\vdots$ \\
$\vdots$ \\
$\vdots$ \\
0 \\
$\vdots$ \\
$\vdots$ \\
$\vdots$ \\
$\vdots$ \\
$\vdots$ \\
$\vdots$ \\
$\vdots$ \\
$\vdots$ \\
0 \\
\end{tabular} & 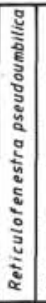 & 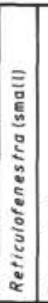 & 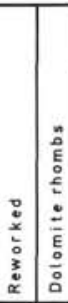 & $\begin{array}{l}c \\
0 \\
\\
0 \\
\vdots \\
\vdots \\
\vdots \\
\vdots \\
\vdots\end{array}$ & 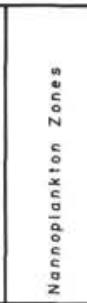 \\
\hline $1 \mathrm{H}-1,89-90 \mathrm{~cm}$ & $R$ & & $R$ & & $R$ & $\mathrm{C}$ & C & C & & & & & 0 & NN 21 \\
\hline $1 \mathrm{H}-6,125 \mathrm{~cm}$ & & & $R$ & & & $\mathrm{~F}$ & A & & & & & & G/M & \multirow{5}{*}{ NN 20} \\
\hline $1 \mathrm{H}, \mathrm{CC}$ & & & & & & $R$ & $R$ & & & & & & $P / M$ & \\
\hline $2 \mathrm{H}-2,38-39 \mathrm{~cm}$ & & R & $\mathrm{R}$ & & & $\mathrm{F}$ & $\mathrm{F}$ & $\mathrm{R}$ & & & & & $0 / M$ & \\
\hline $2 \mathrm{H}, \mathrm{CC}$ & & & & & & $R$ & $\mathrm{~F}$ & $R$ & & & & & M & \\
\hline $3 \mathrm{H}-2,67-48 \mathrm{~cm}$ & & & $R$ & & & $\mathrm{~F}$ & C & \begin{tabular}{|l|}
$R$ \\
\end{tabular} & & & & & M & \\
\hline $3 \mathrm{H}, \mathrm{CC}$ & \multicolumn{13}{|c|}{ bar $r$ en } & $?$ \\
\hline $4 \mathrm{H}-3,117 \mathrm{~cm}$ & & & $\mathrm{~F}$ & & & $\mathrm{~A}$ & & $F$ & & & & & G/M & NN 20 \\
\hline $6 \mathrm{H}, \mathrm{CC}$ & \multicolumn{13}{|c|}{ barren } & $?$ \\
\hline $5 \mathrm{H}-2,26-27 \mathrm{~cm}$ & & & ct. & & & $\mathrm{C}$ & $\mathrm{F}$ & $\mathrm{F}$ & & & & & M & \multirow{2}{*}{ NN 20} \\
\hline $5 \mathrm{H}, \mathrm{CC}$ & & $R$ & & & & $R$ & $R$ & & & & & & $P / M$ & \\
\hline EH,C C & \multicolumn{13}{|c|}{ barren } & $?$ \\
\hline $7 \mathrm{H}-1,101-102 \mathrm{~cm}$ & & $\mathrm{~F}$ & & & & $\mathrm{R}$ & $\mathrm{F}$ & $R$ & & & & & M & NN 20 \\
\hline $7 \mathrm{H}, \mathrm{CC}$ & \multirow{2}{*}{\multicolumn{13}{|c|}{$b a r+e n$}} & $?$ \\
\hline $8 \mathrm{H}, \mathrm{CC}$ & & & & & & & & & & & & & & $e^{\prime}$ \\
\hline $9 \mathrm{H}, \mathrm{CC}$ & & & & & & $R$ & $R$ & $R$ & $R$ & & & & P/M & \multirow{7}{*}{ NN 19} \\
\hline $10 \mathrm{H}-3,50-51 \mathrm{~cm}$ & & & $R$ & & & $R$ & $\mathrm{R}$ & & ct. & & & & $P / M$ & \\
\hline $10 \mathrm{H}, \mathrm{cc}$ & & & & & & $R$ & & $R$ & & & & $>$ & $P / M$ & \\
\hline $11 \mathrm{H}, \mathrm{cc}$ & & $R$ & & & & $R$ & $R$ & & & & & 8 & $P / M$ & \\
\hline $12 \mathrm{H}, \mathrm{cc}$ & & $R$ & & & & $\mathrm{~F}$ & & $R$ & & & & & M & \\
\hline $13 x, c e$ & & $R$ & & & & $\mathrm{~F}$ & $R$ & & & & & & M & \\
\hline $16 x, c c$ & & $F$ & & $R$ & & $\mathrm{~F}$ & $R$ & & & & & & M & \\
\hline Cores $15 x$ to $18 x$ & \multicolumn{13}{|c|}{ barren } & $?$ \\
\hline $19 x, c c$ & & $\mathrm{~F}$ & $R$ & & & $\mathrm{R}$ & $R$ & & & $R$ & $R$ & $T$ & M & $?$ \\
\hline $20 x, c c$ & \multicolumn{13}{|c|}{ barten } & $?$ \\
\hline
\end{tabular}

Note: $\mathrm{R}=$ rare, $\mathrm{F}=$ few, $\mathrm{C}=$ common, $\mathrm{A}=$ abundant. Preservation: $\mathrm{P}=$ poor, $\mathrm{M}=$ moderate, $\mathrm{G}=$ good.

were identified in Cores 112-682A-34X to $-36 \mathrm{X}$, despite the absence of Sphenolithus belemnos. Triquetrorhabdulus carinatus is present in well-preserved specimens, and rare Discoaster druggii also were noted. Because the abundance of siliceous components declines markedly in the early Miocene at this site, the sedimentation rate is low and the lower Miocene sequence seems to be much less thicker, compared with the middle and upper Miocene sequence.

The Oligocene is represented by Cores 112-682A-37X to $-44 \mathrm{X}$, but this interval is difficult to subdivide because in the middle and late Oligocene, sphenoliths are not preserved or are missing in the poorly preserved nannoplankton assemblages. On the basis of the presence of Cyclicargolithus abisectus, which has its first occurrence near the base of nannoplankton Zone NP24 (Sphenolithus distentus Zone) and Dictyococcites dictyodus, which just crosses the Oligocene/ Miocene boundary elsewhere, Samples 112-682A-37X-2, 39$40 \mathrm{~cm}$, to $-40 \mathrm{X}-2,100-101 \mathrm{~cm}$, have been placed in the combined Zone NP24/25* (Sphenolithus distentus/S. ciperoensis Zone). The remaining part of Core 112-682A-40X and $-682 A-42 X$ to $-43 X$ are barren of calcareous nannoplankton. In Core 112-682A-41X, a meager nannoplankton assemblage containing rare Cyclicargolithus abisectus and Triquetrorhab- dulus carinatus was noted. This assemblage has been tentatively assigned to the late Oligocene nannoplankton Zone NP24/25*, but also could represent downhole contamination. In Core 112-682A-44X, a moderately preserved nannoplankton assemblage with frequent Reticulofenestra umbilica, Isthmolithus recurvus, and Cyclococcolithus formosus was found, indicating the presence of the early Oligocene nannoplankton Zone NP21 (Ericsonia subdisticha Zone) at this level.

The remaining cores (from Core 112-682A-45X down to the terminal Core $112-682 \mathrm{~A}-48 \mathrm{X}$ at $436.7 \mathrm{mbsf}$ ) are of middle Eocene age. An uppermost Eocene sequence was not recovered, and a hiatus has been postulated between the early Oligocene and middle Eocene. Discoaster saipanensis, which has its first occurrence near the top of Zone NP16 (Discoaster tani nodifer Zone), is found throughout Cores 112-682A-45X to $-48 \mathrm{X}$, together with rare Chiasmolithus solitus, indicating the upper part of Zone NP16. The occurrence of the nearshore and shallow-water genera Braarudosphaera and Discolithina in the early Oligocene Core 112-682A-44X and in middle Eocene Cores 112-682A-45X to $-48 \mathrm{X}$ (in the latter cores associated with representatives of the genus Micrantholithus) indicates a shallower paleodepth for Site 682 during the early Oligocene and late middle Eocene than their paleodepth from the late Oligocene to Holocene interval (Core 112-682A-41X to $-1 \mathrm{H}$ ).

Reworked calcareous nannoplankton were observed at two intervals. The most obvious reworking took place in the early Oligocene because in samples from Core 112-682A$44 X$, Upper Cretaceous species occur frequently. These include Watznaueria barnesae, Cretarhabdus crenulatus, and Tetralithus trifidus (the latter primarily occurring only in the upper Campanian and lower Maestrichtian). The other interval includes at least Cores $112-682 \mathrm{~A}-15 \mathrm{X}$ to $-23 \mathrm{X}$, where lower Miocene species, such as Helicosphaera ampliaperta and Discoaster deflandrei, were scattered in late middle Miocene to early upper Miocene nannoplankton assemblages.

\section{Site $683\left(9^{\circ} 01.69^{\prime} \mathrm{S}, 80^{\circ} 24.40^{\prime} \mathrm{W}\right.$; water depth, $3071.8 \mathrm{~m}$ )}

Site 683 was chosen to investigate the vertical tectonic movement of the Peruvian continental margin. Two holes were drilled, with an overlap between 402.5 and 419.2 mbsf. Hole $683 \mathrm{~B}$ was terminated at $488.0 \mathrm{mbsf}$ in middle Eocene sediments.

Quaternary calcareous nannoplankton was found in Hole $683 \mathrm{~A}$ in monotonous assemblages down to Core 112-683A$9 \mathrm{H}$, with boundaries between Zones NN20 (Gephyrocapsa oceanica Zone) and NN21 (Emiliania huxleyi Zone) within Core 112-683A-1H and between Zone NN19 (Pseudoemiliania lacunosa Zone) and NN20 (G. oceanica Zone) in Core 112-683A-7X (Table 6). These assemblages are dominated by Gephyrocapsa species; all other species, such as Helicosphaera carteri, Coccolithus pelagicus, and Cyclococcolithus leptoporus, forming only minor constituents. Scattered blooms were noted, with the most obvious blooms occurring in Samples 112-683A-9H-5, $2 \mathrm{~cm}$ (74.7 mbsf) and $-15 \mathrm{X}-1,2 \mathrm{~cm}$ (125.7 mbsf), with the latter probably of Pliocene age.

The interval between Cores 112-683A-10X and $-26 \mathrm{X}$ is barren of calcareous nannoplankton, with the exception of the above-mentioned bloom in Core 112-683A-15X and part of Core 112-683A-19X, where an insignificant nannoplankton assemblage was observed. This assemblage includes, besides common Gephyrocapsa species, rare to few Coccolithus pelagicus, C. miopelagicus, Cyclococcolithus leptoporus, and 
Table 5. Distribution of calcareous nannoplankton in selected samples from Hole 682A and indication of standard nannoplankton zones.

\begin{tabular}{|c|c|c|c|c|c|c|c|c|c|c|c|c|c|c|c|c|c|c|c|c|}
\hline & 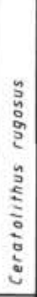 & 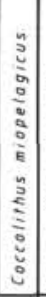 & 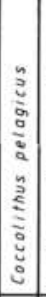 & 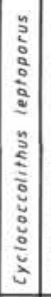 & 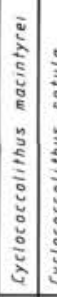 & 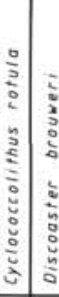 & 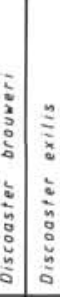 & 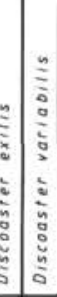 & 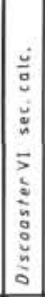 & 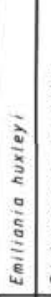 & 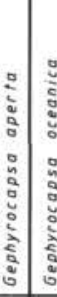 & 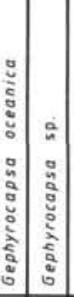 & 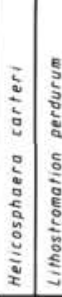 & 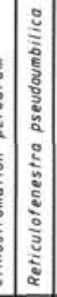 & 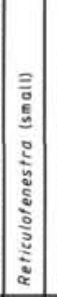 & 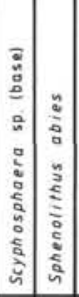 & 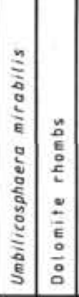 & 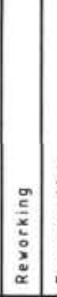 & $\begin{array}{l} \\
\\
\\
\vdots \\
\vdots \\
\vdots \\
\vdots \\
\vdots \\
\vdots \\
\vdots \\
\vdots \\
\vdots\end{array}$ & 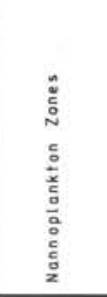 \\
\hline $1 \mathrm{H}-2,95-96 \mathrm{~cm}$ & & & c & $R$ & & & & & & $\mathrm{~F}$ & \begin{tabular}{l|l}
$\mathrm{C}$ & $\mathrm{F}$ \\
\end{tabular} & $\mathrm{F}$ & $\mathrm{F}$ & & & & $\mathrm{F}$ & & 5 & NN 21 \\
\hline $1 \mathrm{H}-6,65-66 \mathrm{~cm}$ & & & $R$ & & & & & & & & $\mathrm{~F}$ & $F$ & $R$ & & & & & & PIM & \multirow{4}{*}{ NN 20} \\
\hline $2 \mathrm{H}-3,7-8 \mathrm{~cm}$ & & & $\mathrm{~F}$ & $R$ & & & & & & & $A$ & $\mathrm{~F}$ & $\mathrm{~F}$ & & & & $\mathrm{R}$ & & $M$ & \\
\hline $2 \mathrm{H}, \mathrm{Ct}$ & & & $R$ & c & & & & & & & $\mathrm{A}$ & $F$ & $F$ & & & & & & M & \\
\hline $3 \mathrm{H}-3.69-70 \mathrm{~cm}$ & & & $R$ & $F$ & & & & & & & $A$ & $F$ & $R$ & & & & & \begin{tabular}{l|l}
$M$ & 1 \\
\end{tabular} & $M$ & \\
\hline $3 \mathrm{H}, \mathrm{CL}$ & \multirow{2}{*}{\multicolumn{19}{|c|}{ baren }} & \multirow{2}{*}{$?$} \\
\hline cores $6 \mathrm{H}$ to $6 \mathrm{H}$ & & & & & & & & & & & & & & & & & & & & \\
\hline $7 x-2,89-90 \mathrm{~cm}$ & & & $R$ & & & & $\mathrm{R}$ & & & & & $F$ & & & & $R$ & & & PIM & \multirow{2}{*}{ NN $16 / 18$} \\
\hline $7 x, c e$ & & & $R$ & $R$ & & & $R$ & & & & & $\mathrm{~F}$ & $R$ & & & & & & PIM & \\
\hline $8 x-1,46-45 \mathrm{~cm}$ & $R$ & & c & $\mathrm{F}$ & $R$ & & $R$ & & & & & $F$ & & $\mathrm{~F}$ & $F$ & $R$ & & & $M$ & NN 15 \\
\hline $8 x, t t$ & \multirow{2}{*}{\multicolumn{19}{|c|}{ borten }} & \multirow{8}{*}{$\begin{array}{c}-N N 6 \\
\text { to } \\
-N N 10\end{array}$} \\
\hline Cores $9 x$ to $14 x$ & & & & & & & & & & & & & & & & & & & & \\
\hline $15 x, 06$ & & $F$ & $F$ & & & & \begin{tabular}{l|l}
$R$ & it \\
\end{tabular} & $\begin{array}{ll} & R \\
\end{array}$ & $R$ & & & & $R$ & $F$ & $F$ & $R$ & & $\begin{array}{ll}M \\
\end{array}$ & M & \\
\hline $16 \mathrm{x}-1,21-22 \mathrm{~cm}$ & & $R$ & \begin{tabular}{l|l}
$R$ \\
\end{tabular} & \begin{tabular}{|l|l}
$R$ & \\
\end{tabular} & $R$ & & & $R$ & $R$ & & & & . & $R$ & $F$ & & & & M & \\
\hline $17 x, 06$ & & $R$ & $\mathrm{~F}$ & & & & $f$ & $R$ & $R$ & & & & $R$ & $F$ & $c$ & $R$ & $\Delta$ & $M P$ & PIM & \\
\hline $18 \times, c 6$ & & $R$ & $\mathrm{~F}$ & & & & $R$ & & $R$ & & & & $R$ & c & c & $R$ & $\diamond$ & $M P$ & $P / M$ & \\
\hline $19 \times, \mathrm{cc}$ & & $R$ & $\mathrm{~F}$ & & & & $R$ & $R$ & $R$ & & & & \begin{tabular}{l|l}
$R$ & $R$ \\
\end{tabular} & $F$ & c & $F$ & & $M P$ & PIM & \\
\hline $20 x, c e$ & & $\mathrm{R}$ & $F$ & & & $R$ & $R$ & $R$ & & & & & $\mathrm{R}$ & $F$ & C & $R$ & $\diamond$ & $M P$ & PIM & \\
\hline Core $21 x$ & \multicolumn{19}{|c|}{ ba $\mathrm{c}$ ren } & $?$ \\
\hline $22 x, 0 t$ & & $R$ & $R$ & $R$ & & & $R$ & $R$ & $\mathrm{R}$ & & & & 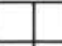 & $R$ & $F$ & & $\diamond$ & \begin{tabular}{|l|l}
$M$ & $P$ \\
\end{tabular} & PIM & \multirow{8}{*}{$\begin{array}{c}-N N 6 \\
\text { to } \\
-N N 10\end{array}$} \\
\hline $23 \times-1,107-112 \mathrm{~cm}$ & & & $F$ & & \begin{tabular}{l|l}
$R$ & $R$ \\
\end{tabular} & $\mathrm{R}$ & $R$ & 2 & $R$ & & & & $R$ & $R$ & $F$ & $R$ & $\diamond$ & $M$ & $P$ & \\
\hline $26 x, 40$ & & & $R$ & & & & $\mathrm{R}$ & & $R$ & & & & $R$ & $R$ & $\mathrm{R}$ & $R$ & $\diamond$ & & $P$ & \\
\hline $25 x, \mathrm{tc}$ & & & & & & & & & & & & & & $R$ & & & $\diamond$ & & $p$ & \\
\hline $26 \times .40$ & & & $R$ & & & & $R$ & $R$ & $R$ & & & & & $\mathrm{~F}$ & $R$ & & $\diamond$ & & $P$ & \\
\hline $27 x, 46$ & & & $R$ & & & & & & $R$ & & & & & $\mathrm{R}$ & $R$ & & $\diamond$ & & $p$ & \\
\hline $28 \times, c 6$ & & $\mathrm{R}$ & $R$ & & & & \begin{tabular}{l|l}
$R$ & $R$ \\
\end{tabular} & ? & & & & & & $F$ & c & $R$ & & \begin{tabular}{l|l}
$M$ & $P$ \\
\end{tabular} & $P, M$ & \\
\hline $29 \times .46$ & & & $R$ & & & & & & & & & & & $R$ & $R$ & & & \begin{tabular}{l|l}
$M$ & $P$ \\
\end{tabular} & PM & \\
\hline core $30 x$ & \multirow{2}{*}{\multicolumn{19}{|c|}{ botren }} & \multirow{2}{*}{$?$} \\
\hline $31 x, c e$ & & & & & & & & & & & & & & & & & & & & \\
\hline
\end{tabular}

Note: $\mathrm{R}=$ rare, $\mathrm{F}=$ few, $\mathrm{C}=$ common, $\mathrm{A}=$ abundant. Preservation: $\mathrm{P}=$ poor, $\mathrm{M}=$ moderate, $\mathrm{G}=$ good. Reworking: $\mathrm{C}=$ Cretaceous, $\mathrm{E}=$ Eocene, $\mathrm{M}=$ Miocene.

rare specimens of Cyclococcolithus macintyrei and Discoaster brouweri. Because Reticulofenestra pseudoumbilica could not be found, this assemblage is of late Pliocene age and may represent nannoplankton Zone NN18 (Discoaster brouweri Zone).

From Core 112-683A-27X down to terminal Core 112$683 \mathrm{~A}-45 \mathrm{X}$ at $419.2 \mathrm{mbsf}$, calcareous nannoplankton is present in slumped material from middle Miocene strata, except in a barren interval between Cores 112-683A-34X and -38X. Upper Miocene sediments were not found. Even though most samples represent slumped material, nannoplankton assemblages seem to be in normal and descending order (Table 6), which was ascertained on the basis of silicoflagellates (Marti$\mathrm{ni}$, this volume). Within this sequence, one core containing a younger nannoplankton assemblage was identified; this assemblage is intercalated in a part that probably represents nannoplankton Zone NN6 (D. exilis Zone). Core 112-863A$30 \mathrm{X}$ can be placed with certainty in the middle Miocene nannoplankton Zone NN8 (Catinaster coalitus Zone), based on the presence of the nominate species in several samples (Pl. 2, Figs 19-21) within this core. Core 112-683A-39X represents nannoplankton Zone NN6 $(D$. exilis Zone), with common Cyclicargolithus floridanus and few Discoaster exi lis. In Cores 112-683A-40X to $-45 \mathrm{X}$, nannoplankton Zone NN5 (Sphenolithus heteromorphus Zone) was ascertained on the basis of the frequent presence of Sphenolithus heteromorphus and the absence of Helicosphaera ampliaperta throughout the cores.

Preservation is good to moderate in the Quaternary part of the sequence and only moderate to poor in the slumped material, depending on the amount of disturbance and sorting of the assemblages. A nearly pure, discoasterbearing layer was found in Sample 112-683A-42X, CC (381.9 mbsf), associated with abundant and concentrated diatoms of the genus Thalassiothrix and a flood of slightly rounded dolomite rhombs.

In Hole 683B, Cores 112-683B-1X to- $6 \mathrm{X}$ contain middle Miocene calcareous nannoplankton assemblages that belong 
Table 5 (continued).

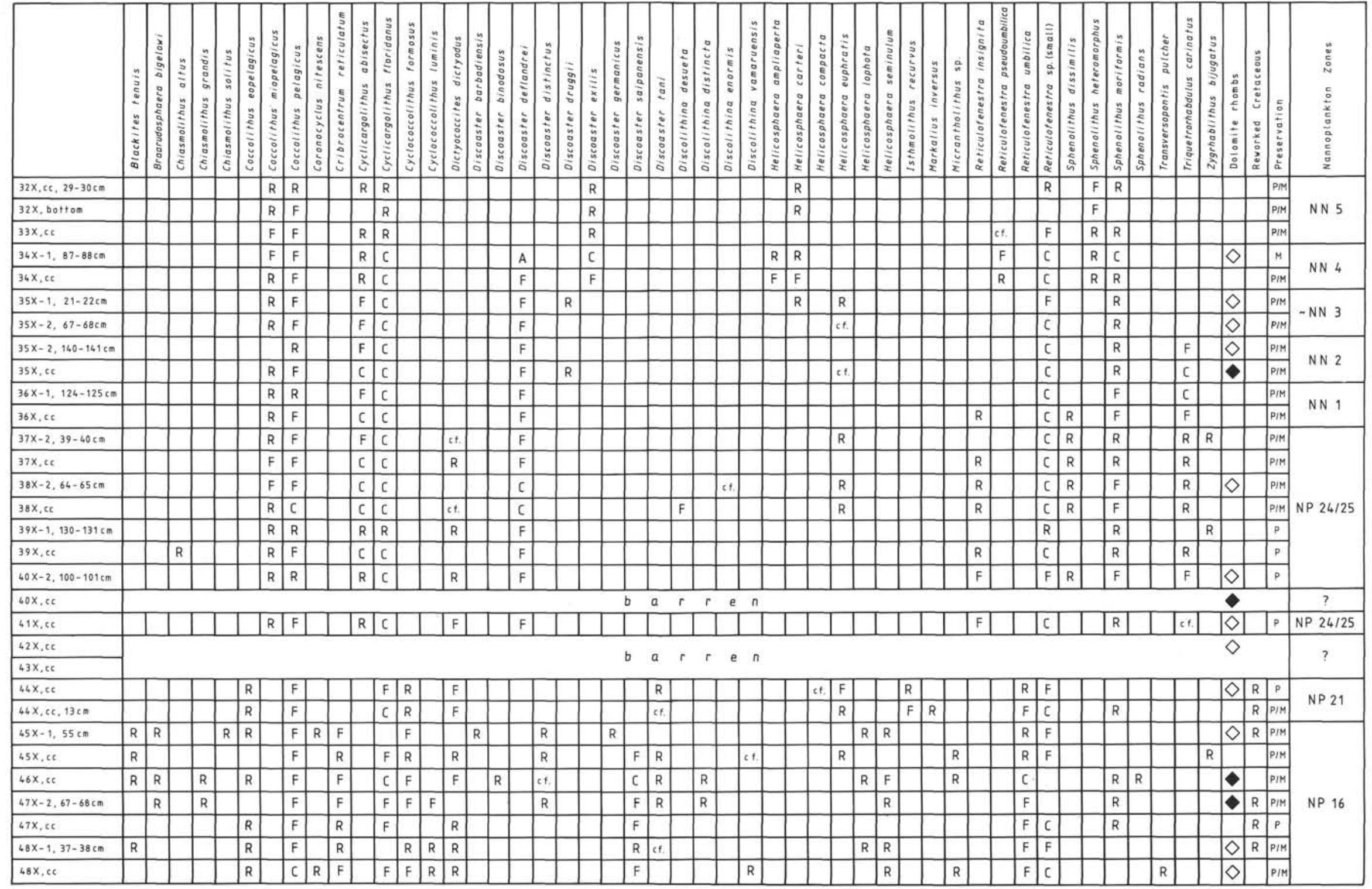


to nannoplankton Zone NN5 (Sphenolithus heteromorphus Zone), based on the presence of Sphenolithus heteromorphus and the absence of Helicosphaera ampliaperta. Cores 112$683 \mathrm{~B}-1 \mathrm{X}$ and $-2 \mathrm{X}$ are from the same level as Cores 112$683 \mathrm{~A}-44 \mathrm{X}$ and $-45 \mathrm{X}$.

Moderately preserved middle Eocene calcareous nannoplankton was observed in Core 112-683B-7X. This observation signifies a prominent hiatus between Cores 112-683B-6X and -7X, with part of the middle Eocene, upper Eocene, Oligocene, and lower Miocene missing. Thus, this hiatus covers a time interval of approximately 28 m.y. The upper part of Core 112-683B-7X down to Sample 112-683B-7X-2, 98-99 cm (462 mbsf) can be placed in nannoplankton Zone NP17 (Discoaster saipanensis Zone), with the nominate species present in fair numbers. In Sample 112-683B$7 \mathrm{X}-3,30 \mathrm{~cm}$, and in samples below, Chiasmolithus solitus was found, the last occurrence of which indicates the top of nannoplankton Zone NP16 (Discoaster tani nodifer Zone). Accordingly, this sample marks Zone NP6, which extends down to terminal Core 112-683B-9X (total depth, 488.0 mbsf). However, Samples 112683B-7X, CC, and -8X, CC (30 cm), contain nannoplankton Zone NP17 and may represent downhole contamination.

Cores $112-683 \mathrm{~B}-8 \mathrm{X}$ and $-9 \mathrm{X}$ were greatly disturbed by drilling and contain Eocene sediments, together with displaced Miocene material from above. Miocene contamination was recognized in Samples 112-683B-8X, CC $(10 \mathrm{~cm}),-683 \mathrm{~B}-$ $8 \mathrm{X}, \mathrm{CC},-683 \mathrm{~B}-9 \mathrm{X}, \mathrm{CC}(2 \mathrm{~cm})$, and $-683 \mathrm{~B}-9 \mathrm{X}, \mathrm{CC}$. Shallowwater species, such as Zygrhablithus bijugatus, Braarudosphaera bigelowi, Micrantholithus sp., and Discolithina species, were found in the Eocene part of Hole 683B, but in lesser numbers than at Site 682 .

\section{Site $684\left(8^{\circ} 59.59^{\prime} \mathrm{S}, 7^{\circ} 54.35^{\prime} \mathrm{W}\right.$; water depth, $426.0 \mathrm{~m}$ )}

This site is the northern point of a transect of three north-south directed sites along the upper-slope deposits of the Peruvian margin. One Leg 112 objective was to investigate the latitudinal variability of upwelling parameters. Three holes were drilled at this site; however, only Hole 684A was investigated in detail for calcareous nannoplankton, which was found with distinct assemblages in three different intervals.

Core-112 $684 \mathrm{~A}-1 \mathrm{H}$ and part of $-2 \mathrm{H}$ contain a monotonous nannoplankton assemblage of the late Quaternary. Gephyrocapsa oceanica and Gephyrocapsa aperta are always present and are accompanied by rare Cyclococcolithus leptoporus and abundant Helicosphaera carteri (Table 7). Some reworked specimens from the Neogene were observed in Sample 112684A-1H-2, 84-86 cm (2.3 mbsf).

The lowest part of Core 112-684A-3H and the upper part of Core $112-684 \mathrm{~A}-4 \mathrm{H}$ are barren of calcareous nannoplankton.

In Samples 112-684A-4H, CC (33.6 mbsf), and -5H, CC, rare Discoaster surculus were noted. Discoaster brouweri was found in several samples from Cores $112-684 \mathrm{~A}-5 \mathrm{H}$ and $-6 \mathrm{H}$, together with Discoaster tamalis in Sample 112-684A-6H-3, $98 \mathrm{~cm}$ (47.3 mbsf). Because Reticulofenestra pseudoumbilica is absent in all samples, this interval is placed in the late Pliocene nannoplankton Zone NN16 (Discoaster surculus Zone).

In the interval between Samples 112-684A-6H, CC, and $-7 \mathrm{H}-5,57-58 \mathrm{~cm}$ (51-59.4 mbsf), an assemblage dominated by Reticulofenestra pseudoumbilica and related species is present. Rare Discoaster hamatus in Samples 112-684A-7H-6, $80-81 \mathrm{~cm}$, and $-8 \mathrm{H}-1,9-10 \mathrm{~cm}(61.1$ and $62.4 \mathrm{mbsf}$, respectively), down to $-13 \mathrm{X}, \mathrm{CC}$ (107.9 mbsf), allow one to place the interval in nannoplankton Zone NN9 (Discoaster hamatus Zone). Sample 112-684A-14X, CC, probably also belongs in Zone NN9 because Catinaster coalitus, a species indicative of the next lower Zone NN8, was not found, even though it was observed at nearby Site 683. Braarudosphaera bigelowi was observed frequently in Sections $112-684 \mathrm{~A}-8 \mathrm{H}-2$ and $8 \mathrm{H}-3$, as well as in Sample 112-684C-8X, CC (60.4 mbsf). Together with Discolithina species in Cores 112-684A-8X to $-14 \mathrm{X}$ (Table 7), Braarudosphaera bigelowi indicates nearshore and shallow-water conditions for the area during deposition of this late middle Miocene sequence. Blooms of Reticulofenestra species were noted at several levels. Preliminary study of selected light-colored thin layers in equivalent strata of Hole $684 \mathrm{C}$ indicates the presence of many Reticulofenestra blooms. Complete spheres are frequent in these layers (resulting from blooms) and indicate rapid accumulation and undisturbed settlement. Scyphosphaera species (PI. 2, Figs. 1-8) occur frequently in Cores $112-684 \mathrm{~A}-13 \mathrm{X}$ and $-684 \mathrm{C}-13 \mathrm{X}$ at the same level near the bottom of the drilled sequence (at approximately 107 mbsf in both cases) and also are found above this level. A nearly identical assemblage is present in the slightly younger sequence (nannoplankton Zone NN10, Discoaster calcaris Zone) from Gabun on the west coast of Africa (Martini, 1969), deposited under similar conditions but that assemblage is associated with Coccolithus pelagicus, which commonly indicates cold-water influences in marine sediments. This species is missing in the assemblages of late middle Miocene age at Site 684 .

According to these nannoplankton data, two hiatuses divide the assemblages. One hiatus is present in the lowest part of Core $112-684 \mathrm{~A}-2 \mathrm{H}$ at approximately $15 \mathrm{mbsf}$, with the lower part of the Quaternary and the uppermost Pliocene (equivalent to $2.0 \mathrm{~m} . \mathrm{y}$.) missing. The other hiatus is between Core $112-684 \mathrm{~A}-6 \mathrm{H}$ and $-7 \mathrm{H}$ at approximately $52 \mathrm{mbsf}$, where the lower Pliocene and most of the upper Miocene (equivalent to 5.4. m.y.) is missing.

Samples from Hole 684B and from the upper part of Hole $684 \mathrm{C}$ were not investigated because of the meager nannoplankton assemblages encountered in Hole $684 \mathrm{~A}$ at these levels.

\section{Site $685\left(9^{\circ} 06.78^{\prime} \mathrm{S}, 80^{\circ} 35.01^{\prime} \mathrm{W}\right.$; water depth, $\mathbf{5 0 7 0 . 8} \mathrm{m}$ )}

Site 685 was located so as to sample the oldest part of the sediment accreted to the Peru Trench during the Andean orogeny. Only one hole was drilled.

Cores $112-685 \mathrm{~A}-1 \mathrm{H}$ to $-22 \mathrm{X}$ (199.8 mbsf) contain meager Quaternary nannoplankton assemblages at some levels, but are frequently barren or yield only a few poorly preserved Gephyrocapsa specimens. Some better preserved assemblages occur in Samples 112-685A-3H-2, 19-20 cm, -685A$4 \mathrm{H}, \mathrm{CC}$, and between 112-685A-6X, CC, and -685A-10X-4, 98-99 cm. These include Gephyrocapsa oceanica, G. aperta, Helicosphaera carteri, Coccolithus pelagicus, and Cyclococcolithus leptoporus (Table 8). Samples between Cores 112$685 \mathrm{~A}-3 \mathrm{H}$ and $-7 \mathrm{X}$ may represent nannoplankton Zone NN20 (Gephyrocapsa oceanica Zone) of the late Quaternary. Samples below this and down to Core 112-685A-22X may belong to Zone NN19 (Pseudoemiliania lacunosa Zone) because rare Pseudoemiliania lacunosa were found in Samples 112-685A$8 \mathrm{X}-4,24-25 \mathrm{~cm}$, and $-12 \mathrm{X}-2,98-99 \mathrm{~cm}$.

A hiatus of $4.3 \mathrm{~m} . \mathrm{y}$. duration was noted between Cores $112-685 \mathrm{~A}-22 \mathrm{X}$ and $-23 \mathrm{X}$ at 200 mbsf, dividing the Quaternary from the late Miocene. In Samples 112-685A-23X, CC (203.6 mbsf) and -25X-1, $3 \mathrm{~cm}$ (222.6 mbsf), Discoaster quinqueramus was found frequently with Reticulofenestra pseudoumbilica, Reticulofenestra sp. (small), rare Sphenolithus abies, Coccolithus pelagicus, Cyclococcolithus leptoporus, and a few unidentifiable six-rayed discoasters having calcite overgrowth (Table 8). In Sample 112-685A-25X, CC, only a few 
Discoaster quinqueramus were observed. Based on calcareous nannoplankton, the interval between Cores 112-685A-23X and $-25 \mathrm{X}$ (Nothing was recovered from Core 112-685A-24X) can be placed in the late Miocene nannoplankton Zone NN11 (Discoaster quinqueramus Zone). Sample 112-685A-26X, CC (232.1 mbsf), contained only a few well-preserved Discoaster calcaris, but as $D$. quinqueramus was not found, this sample is assigned to the late Miocene nannoplankton Zone NN10 (Discoaster calcaris Zone).

Cores 112-685A-27X through -51X (235.2-459.1 mbsf) are barren of calcareous nannoplankton, with the exception of Cores 112-685A-38X, $-44 \mathrm{X},-48 \mathrm{X}$, and $-50 \mathrm{X}$. In Cores $112-$ $685 \mathrm{~A}-38 \mathrm{X}$ and $-48 \mathrm{X}$, a poorly preserved, partially recrystallized nannoplankton assemblage was observed in a snowflakelike background of tiny calcite particles. A single specimen of Discoaster calcaris was noted among frequent Reticulofenestra sp. and rare Sphenolithus abies, as well as Coccolithus pelagicus in Sample 112-685A-38X-1, $36 \mathrm{~cm}(338.6$ mbsf), indicating that this level may still belong to nannoplankton Zone NN10.

In Cores 112-685A-44X (392.6-396.1 mbsf) and -50X (449.6-450.6 mbsf), slumped material was recovered that contains a mixture of lower Miocene and middle to upper Eocene nannoplankton. Oligocene nannoplankton was not found. Nannoplankton in selected clasts from Core 112$685 \mathrm{~A}-44 \mathrm{X}$ reveals that besides purely lower Miocene and Eocene clasts, a number of lower Miocene ones are present that also contain Eocene nannoplankton, obviously reworked in early Miocene time from older strata. Nannoplankton assemblages in some of the clasts in Cores 112-685A-44X and $-50 \mathrm{X}$ were identified and are shown in Table 9.

According to the occurrence of only discoaster-bearing samples, poorly preserved coccolith assemblages, and barren samples, most of the sequence was deposited well below the local carbonate compensation depth (CCD). The interval between Cores 112685A-23X and -26X (203.6-232.1 mbsf), however, was deposited approximately at the local CCD, with Samples 112-685A-25X, CC (223 mbsf) and -26X, CC (232.1 mbsf) just below this level. The same may apply for Cores 112-685A-38X (338.1-338.6 mbsf) and $-48 \mathrm{X}$ (430.6-440.5 mbsf).

Based on nannoplankton data, the sedimentation rate in the Quaternary sediments (NN19 to NN21) may exceed 107 $\mathrm{m} / \mathrm{m}$.y. (interval at 0 to $199.8 \mathrm{mbsf}$ ) and in the late Miocene (NN10) may exceed $168 \mathrm{~m} / \mathrm{m}$.y. (interval at 232.1 to 459.1 mbsf) at this site. Dip of the sediments was not considered for these calculations.

\section{Site $686\left(13^{\circ} 28.81^{\prime} \mathrm{S}, 7^{\circ} 53.49^{\prime} \mathrm{W}\right.$; water depth, $446.8 \mathrm{~m}$ )}

At Site 686, which also was selected to study the upwelling system off Peru, most samples from the two holes drilled are barren in calcareous nannoplankton. From approximately $60 \mathrm{mbsf}$ down to approximately $284 \mathrm{mbsf}$, calcareous nannoplankton was scattered in impoverished and poorly preserved assemblages containing Gephyrocapsa species and rare Helicosphaera carteri (Table 10). Rare Pseudoemiliania lacunosa were found in Samples 112 686A-10X-2, 68-69 cm (74.9 mbsf) and -21X, CC (186.6 mbsf), indicating the presence of nannoplankton Zone NN19 (Pseudoemiliania lacunosa Zone) in the lower part of the sequence. Cyclococcolithus macintyrei is present in Samples 112-686A-19X, CC (167.5 mbsf), and -686A-22X, CC (187.1 mbsf), which can be used to identify the lower part of the Pseudoemiliania lacunosa Zone (Zone NN19a, last occurrence of Discoaster brouweri to last occurrence of Cyclococcolithus macintyrei) and the lowest part of the Quaternary.

In most cases, the meager Quaternary nannoplankton assemblages are associated with displaced lower to middle
Miocene and middle to late Eocene nannoplankton species. These displaced species are especially frequent in the shellbed interval at about 190 mbsf that contains common Calyptraea sp. and some other gastropods (Hagn and Martini, this volume) and where in Sample 112-686A-22X, CC, Discoaster deflandrei, Cyclicargolithus floridanus, Reticulofenestra pseudoumbilica, Dictyococcites dictyodus, and Reticulofenestra umbilica were identified.

Sedimentation rates are at least $160 \mathrm{~m} / \mathrm{m}$.y., if one considers the whole sequence as representing the Quaternary calcareous nannoplankton Zones NN19 (Pseudoemiliania lacunosa Zone) to NN21 (Emiliania huxleyi Zone).

The upper part of Hole 686B is more or less identical with the sequence previously described for Hole 686A. Below 205.7 mbsf, where Hole 686A was terminated, samples from Core $112-686 \mathrm{~B}-24 \mathrm{X}$ to $-32 \mathrm{X}$ contain scattered, poorly preserved nannoplankton or were barren (Table 10). Sample 112-686B-25X, CC, may belong in nannoplankton Zone NN19 ( $P$. lacunosa Zone). The remaining samples could not be assigned to a certain nannoplankton zone.

\section{Site $687\left(12^{\circ} 51.78^{\prime} \mathrm{W}, 7^{\circ} 59.43^{\prime} \mathrm{W}\right.$; water depth, $306.8 \mathrm{~m}$ )}

Two holes were drilled at Site 687 , which was selected to study the Peru coastal upwelling regime. As in the previous site, most of the samples are barren in calcareous nannoplankton. However, Sample 112-687A-1H, CC (7.4 mbsf) contains a well-preserved but poorly diversified late Quaternary nannoplankton assemblage (Table 11). Scattered impoverished and poorly preserved assemblages having $\mathrm{Ge}$ phyrocapsa sp., Coccolithus pelagicus, and rare Helicosphaera carteri were encountered. Helicosphaera sellii was found in Samples 112-687A-14X, CC (127.9 mbsf), -687B9X, CC (81.0 mbsf), -687B-16X, CC (130.0 mbsf), and -687B-22X, CC (185.8 mbsf). Together with the highest occurrence of Cyclococcolithus macintyrei in Sample 112687B-9X, CC (81.0 mbsf), these species may indicate the presence of the early Quaternary nannoplankton Zone NN19 (Pseudoemiliania lacunosa Zone) in this interval.

In some cases, these meager nannoplankton assemblages were associated with rare reworked lower to middle Miocene and middle to upper Eocene nannoplankton species. The displaced species found in Samples 112-687A-19X, CC (175.0 mbsf), -687A-22X, CC (202.0 mbsf), -687B-20X, CC (167.9 mbsf), and -687B-22X, CC (185.8 mbsf) include Discoaster deflandrei, Cyclococcolithus floridanus, Reticulofenestra pseudoumbilica, Dictyococcites dictyodus, Discoaster tani, and Reticulofenestra umbilica.

Between Cores 112-687A-6H and -7X, dolomite rhombs are frequent at several levels, as also indicated in Table 11, and samples are barren or contain only poorly preserved and impoverished nannoplankton assemblages. Sample 112-687B-9X, CC (81.0 mbsf), containing Cyclococcolithus macintyrei, has an age of at least 1.45 Ma, which Backman and Shackleton (1983) assigned for the last occurrence of $C$. macintyrei. Thus, the sedimentation rate in the Quaternary at Site 687 is at least $56 \mathrm{~m} / \mathrm{m} . \mathrm{y}$.

\section{Site $688\left(11^{\circ} 32.26^{\prime} \mathrm{S}, 7^{\circ} 56.57^{\prime} \mathrm{W}\right.$; water depth, $3819.8 \mathrm{~m}$ )}

Objectives of this site were similar to those at Site 682 for establishing the history of vertical tectonism and the oceanic or continental origin of the crystalline basement in a location near the trench. Five holes were drilled at this site, but only Holes $688 \mathrm{~A}$ and $688 \mathrm{E}$ were successful. Hole $688 \mathrm{C}$ yielded only one core, and Holes 688B and 688D were abandoned after drilling failed. 


\section{E. MARTINI}

The first four cores of Hole $688 \mathrm{~A}$ contain a moderately well-preserved late Quaternary nannoplankton assemblage with common Gephyrocapsa oceanica and Gephyrocapsa aperta, few Coccolithus pelagicus, Cyclococcolithus leptoporus, and Helicosphaera carteri (Table 12). Sample 112688A-1H-4, 91-92 cm, can be placed in nannoplankton Zone NN21 (Emiliania huxleyi Zone). The lower part of Core 112-688A-1H down to -688A-4H does not contain Emiliania huxleyi and belongs to nannoplankton Zone NN20 (Gephyrocapsa oceanica Zone). Below this level, Pseudoemiliania lacunosa was scattered, indicating that most of the sequence belongs to the Quaternary nannoplankton Zone NN9 (Pseudoemiliania lacunosa Zone).

From Core 112-688A-14X (12.3 mbsf) downward, barren intervals are frequent and include part of Cores 112-688A-14X to $-16 \mathrm{X}$ (12.3-57.7 mbsf), Cores 112-688A-23X, $-25 \mathrm{X}$ to $-27 \mathrm{X}$ (226.8-253.4 mbsf), part of Cores 112-688A-30X, $-31 \mathrm{X}$, and $-32 \mathrm{X}(283.3-304.6 \mathrm{mbsf})$, as well as $-35 \mathrm{X}$ to $-37 \mathrm{X}(321.3-343.4$ mbsf).

Cyclococcolithus macintyrei in single, poorly preserved specimens was found in Samples 112-688A-6H, CC, and -9X, $\mathrm{CC}$; these are regarded as reworked. This species can be observed more frequently and in better preservation in Core 112-688A-19X (169.8 mbsf), indicating the lower part of nannoplankton Zone NN19 (= NN19a) at this level. Cores 112-688A-24X, $-28 \mathrm{X},-29 \mathrm{X}$, and part of $-32 \mathrm{X}$ to $-34 \mathrm{X}$ contain only rare and, in most cases, also poorly preserved Gephyrocapsa species and Coccolithus pelagicus, and may represent displaced material from upslope. Because of impoverished nannoplankton assemblages and barren intervals, no zonal or age assignment is possible for the sequence below Core $112-688 \mathrm{~A}-22 \mathrm{X}$ (198.7 mbsf) to the terminal depth of Hole $688 \mathrm{~A}$ at 350.3 mbsf.

Two samples from Hole $688 \mathrm{C}$ at 351.0 (112-688C-1R-1, 75 $\mathrm{cm})$ and 351.5 mbsf (112-688C-1R-1, bottom) are barren of calcareous nannoplankton.

In Hole 688E, Cores $112-688 \mathrm{E}-1 \mathrm{R}$ to $-11 \mathrm{R}(350.0-441.0$ mbsf), -19R (517.0-521.8 mbsf), and -26R (583.5-584.6 mbsf) also are barren of calcareous nannoplankton. Between Cores $112-688 \mathrm{E}-12 \mathrm{R}$ and $-21 \mathrm{R}$, middle Miocene calcareous nannoplankton were observed; these cores contain varying numbers of moderately preserved Discoaster exilis, D. variabilis, Reticulofenestra pseudoumbilica, Cyclicargolithus floridanus, and other species. Because Sphenolithus heteromorphus was not found, the nannoplankton assemblages of Cores 112$688 \mathrm{E}-12 \mathrm{R}$ to $-16 \mathrm{R}$ can be placed with certainty in nannoplankton Zone NN6 (Discoaster exilis Zone). Cores 112-688E-17R, $-18 \mathrm{R}$, and $-21 \mathrm{R}$ may contain only caved-in middle Miocene material from above. Between Samples 112-688E-22R-1, 2-3 $\mathrm{cm}$ (545.5 mbsf) and -24R-1, 86-87 cm, and also in Sample 112-688E-25R, CC (576.7 mbsf) below a barren interval, a nannoplankton assemblage dominated by Discoaster deflandrei, Cyclicargolithus floridanus, and Reticulofenestra sp. (small) is present. Coccolithus miopelagicus, C. pelagicus, Cyclicargolithus abisectus, rare Sphenolithus dissimilis, and Triquetrorhabdulus carinatus also were found. As neither Sphenolithus belemnos and Sphenolithus heteromorphus nor Dictyococcites dictyodus and other species having their last occurrence at or near the Oligocene/Miocene boundary were encountered, the above interval is believed to represent the early Miocene nannoplankton Zone NN1 (Triquetrorhabdulus carinatus Zone) and probably Zone NN2 (Discoaster druggii Zone).

A major hiatus was found between Cores 112-688E-26R and -27R. In Core 112-688E-27R, a middle Eocene nannoplankton assemblage is present in Sample 112-688E-27R-1,
Table 6. Distribution of calcareous nannoplankton in selected samples from Holes $683 \mathrm{~A}$ and $683 \mathrm{~B}$ and indications of standard nannoplankton zones.

\begin{tabular}{|c|c|c|c|c|c|c|c|c|c|c|c|c|c|c|}
\hline & 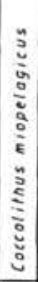 & 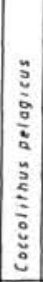 & 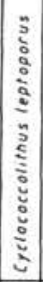 & 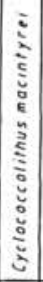 & $\begin{array}{c}\vdots \\
\vdots \\
\vdots \\
\vdots \\
\vdots \\
\vdots \\
\vdots \\
\vdots \\
\vdots \\
\vdots \\
\vdots\end{array}$ & 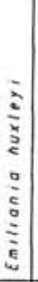 & $\begin{array}{ll} & \\
\vdots & \\
\vdots \\
\vdots \\
\vdots \\
\vdots \\
\vdots \\
\vdots \\
\vdots \\
\vdots \\
\vdots \\
\vdots \\
\vdots \\
\vdots\end{array}$ & $\begin{array}{l}0 \\
\vdots \\
\vdots \\
\vdots \\
\vdots \\
\vdots \\
\vdots \\
\vdots \\
\vdots \\
\vdots \\
\vdots \\
\vdots \\
\vdots\end{array}$ & $\begin{array}{c} \\
\vdots \\
\vdots \\
\vdots \\
\vdots \\
\vdots \\
\vdots \\
\vdots \\
\vdots \\
\vdots \\
\vdots \\
\vdots \\
\vdots \\
x\end{array}$ & \begin{tabular}{c|c} 
\\
$\vdots$ \\
$\vdots$ \\
$\vdots$ \\
$\vdots$ \\
$\vdots$ \\
$\vdots$ \\
$\vdots$ \\
$\vdots$ \\
$\vdots$ \\
$\vdots$ \\
$\vdots$ \\
$\vdots$
\end{tabular} & $\begin{array}{c}: \\
\vdots \\
\vdots \\
\vdots \\
\vdots \\
\vdots \\
\vdots \\
\vdots \\
\vdots \\
\vdots \\
\vdots \\
\vdots \\
\vdots \\
\vdots \\
\end{array}$ & \begin{tabular}{c|c}
0 \\
$\vdots$ \\
$\vdots$ \\
$\vdots$ \\
$\vdots$ \\
$\vdots$ \\
$\vdots$ \\
$\vdots$ \\
$\vdots$ \\
$\vdots$ \\
$\vdots$ \\
$\vdots$ \\
$\vdots$ \\
$\vdots$
\end{tabular} & 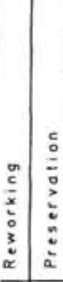 & 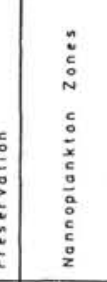 \\
\hline $1 \mathrm{H}-1,112-113 \mathrm{~cm}$ & & & $\mathrm{R}$ & & & $R$ & $\mathrm{~F}$ & C & $F$ & & & & O/M & \begin{tabular}{l|l}
$M$ & NN 21
\end{tabular} \\
\hline iH, ce & & $F$ & $R$ & & & & C & C & $R$ & & & & G/M & M \\
\hline $2 \mathrm{H}, \mathrm{CC}$ & & $R$ & & & & & C & $\mathrm{F}$ & $F$ & & & & M & 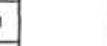 \\
\hline $3 \mathrm{H}-4,103-106 \mathrm{~cm}$ & & & & & & & C & $R$ & A & & & & $O / M$ & M \\
\hline $3 \mathrm{H}, \mathrm{CC}$ & & $R$ & $R$ & & & & $C$ & $\mathrm{~F}$ & $\mathrm{~F}$ & & & & M & \\
\hline $6 \mathrm{H}, \mathrm{CC}$ & & $\mathrm{R}$ & $R$ & & & & C & $F$ & $R$ & & & $R$ & G/M & MN 20 \\
\hline SH,ce & & & $R$ & & & & A & $\mathrm{F}$ & $R$ & & & & $O / M$ & $M$ \\
\hline $6 \mathrm{H}-6,20-21 \mathrm{~cm}$ & & & $R$ & & & & $\mathrm{~A}$ & $R$ & $\mathrm{~F}$ & & & & $G / M$ & \\
\hline $6 \mathrm{H}, \mathrm{cc}$ & & & $R$ & & & & A & $\mathrm{F}$ & $R$ & & & & G/M & M \\
\hline $7 \mathrm{H}-6,95-96 \mathrm{~cm}$ & & $R$ & $R$ & & & & A & $\mathrm{F}$ & $\mathrm{F}$ & & & & M & \\
\hline $7 \mathrm{H}, \mathrm{CC}$ & & $\mathrm{R}$ & $R$ & & & & C & $\mathrm{F}$ & $R$ & & $\mathrm{R}$ & & M & \\
\hline $8 \mathrm{H}, \mathrm{CC}$ & & & c1. & & & & $\mathrm{R}$ & $R$ & & & & & $P$ & NN 19 \\
\hline $9 \mathrm{H}-5,2 \mathrm{~cm}$ & & & & & & & $\mathrm{R}$ & \begin{tabular}{l|l} 
\\
\end{tabular} & $R$ & & A & & $O / M$ & M \\
\hline $9 \mathrm{H}, \mathrm{CC}$ & \multirow{2}{*}{\multicolumn{13}{|c|}{ barten }} & \multirow{4}{*}{$?$} \\
\hline Cores $10 x+1013 x$ & & & & & & & & & & & & & & \\
\hline $16 x, c c$ & & $R$ & & & & & $\mathrm{~F}$ & $R$ & $R$ & $R$ & & & $M$ & \\
\hline $15 x-1,2 \mathrm{~cm}$ & & & $\mathrm{R}$ & & & & A & C & C & & & & G & \\
\hline $15 x, c e$ & \multirow{2}{*}{\multicolumn{13}{|c|}{ baten }} & \multirow{2}{*}{$?$} \\
\hline Cores $16 \times 1018 \mathrm{X}$ & & & & & & & & & & & & & & \\
\hline $19 x, c c$ & $F$ & $R$ & $\mathrm{R}$ & $R$ & $R$ & & C & $\mathrm{F}$ & $R$ & & & & $M$ & NN18 \\
\hline Cores $20 x$ to $26 x$ & \multicolumn{13}{|c|}{$b 0, \ldots n$} & $?$ \\
\hline
\end{tabular}

Note: $\mathrm{R}=$ rare, $\mathrm{F}=$ few, $\mathrm{C}=$ common, $\mathrm{A}=$ abundant. Preservation: $\mathrm{P}=$ poor, $\mathrm{M}=$ moderate, $\mathrm{G}=$ good.

$120 \mathrm{~cm}$ (594.2 mbsf), that includes Chiasmolithus solitus, Reticulofenestra umbilica, Cyclococcolithus formosus, Cribrocentrum reticulatum, Discoaster saipanensis, Discoaster barbadiensis, and Neococcolithes dubius (Table 12). This assemblage can be placed in nannoplankton Zone NP16 (Discoaster tani nodifer Zone) and can be followed down to Sample 112-688E-36R-1, 60-61 cm (679.1 mbsf), although several intervals between these cores are barren or contain only rare, poorly preserved nannoplankton species. A change in the nannoplankton assemblage was noted between Samples 112-688E-36R-1, 60-61 cm, and -36R-2, 18-19 cm; this change is related to another hiatus. In the latter sample, Discoaster saipanensis, Cribrocentrum reticulatum, and $R e$ ticulofenestra umbilica are missing, but rare Discoaster sublodoensis are present, indicating nannoplankton Zone NP14 (Discoaster sublodoensis Zone). Below this sample, Discolithina and Transversopontis species show a significant increase, and Braarudosmhaera bigelowi also was found, indicating a shallower water depth in the middle Eocene. In Sample 112-688E-36R-2, 140-141 cm, and below, Discoaster sublodoensis is missing, but Discoaster lodoensis, Discoaster distinctus, Discoasteroides kuepperi, Cyclococcolithus formosus, and Chiasmolithus solitus are present, and these samples are placed in the early Eocene nannoplankton Zone NP13 (Discoaster lodoensis Zone). The remaining cores, down to terminal Core 112-688E-45R (769.0 mbsf), also 
Table 6 (continued).

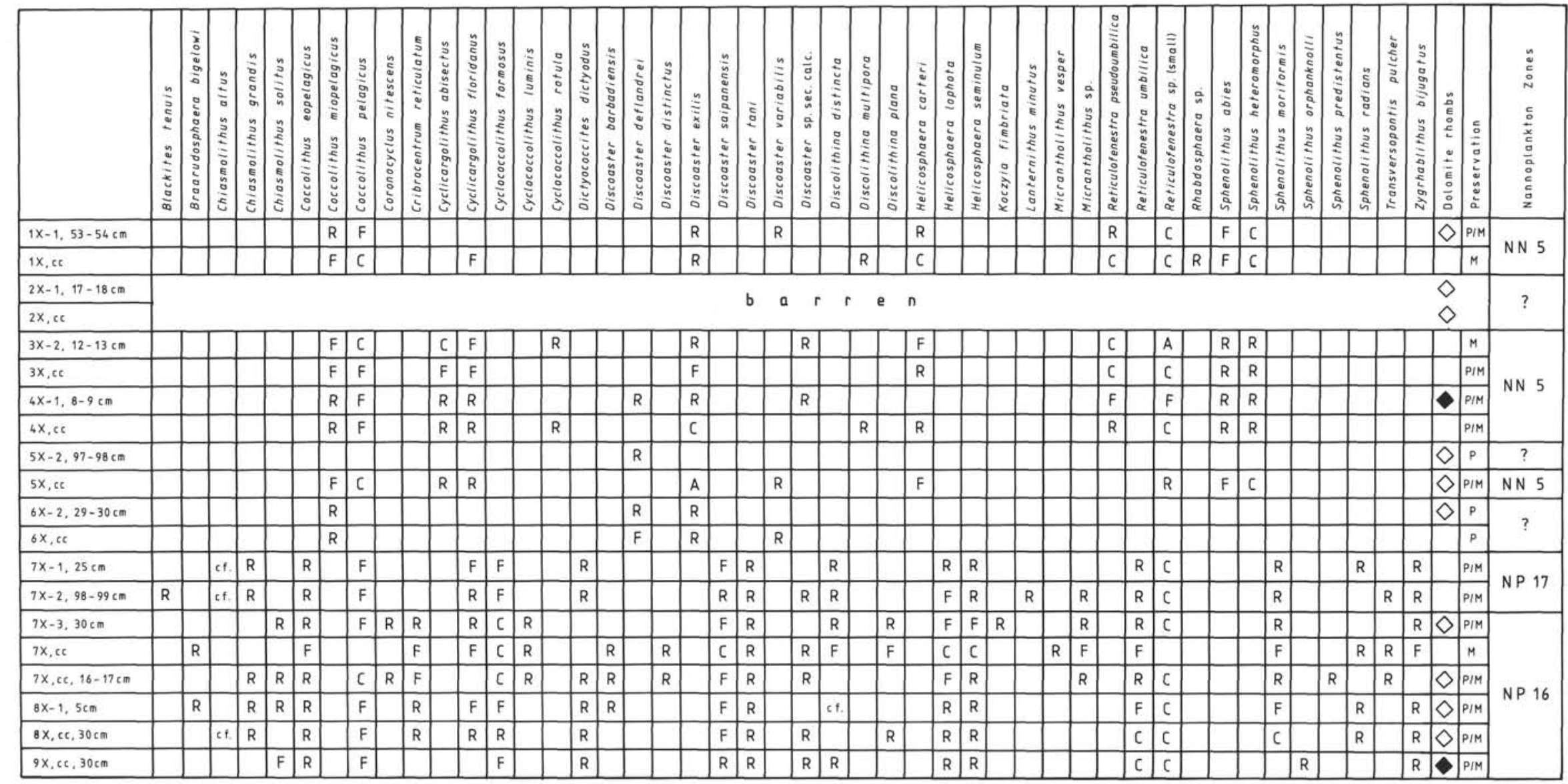


Table 6 (continued).

\begin{tabular}{|c|c|c|c|c|c|c|c|c|c|c|c|c|c|c|c|c|c|c|c|c|c|c|c|c|c|c|c|c|}
\hline & \begin{tabular}{l} 
\\
\multirow{2}{z}{} \\
$\vdots$ \\
$\vdots$ \\
$\vdots$ \\
$\vdots$ \\
$\vdots$ \\
$\vdots$ \\
$\vdots$ \\
$\vdots$ \\
$\vdots$ \\
$\vdots$ \\
$\vdots$
\end{tabular} & 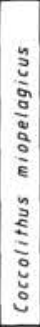 & 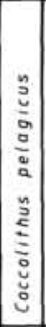 & 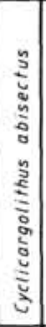 & 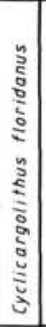 & 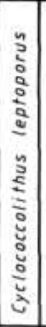 & 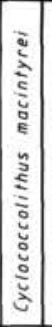 & 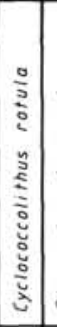 & 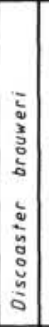 & 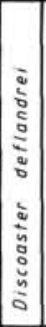 & $\begin{array}{l}n \\
\bar{a} \\
a \\
\vdots \\
\vdots \\
\vdots \\
\vdots \\
\vdots \\
\bar{a} \\
\vdots\end{array}$ & 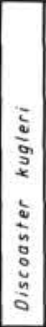 & 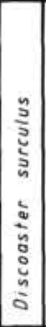 & 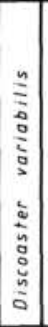 & 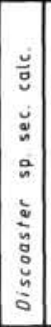 & 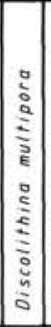 & 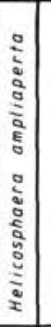 & 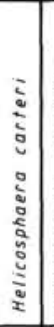 & 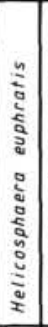 & 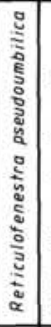 & 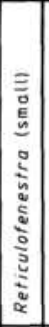 & 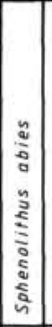 & 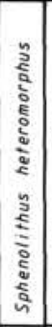 & 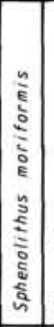 & 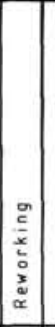 & 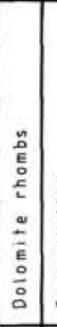 & $\begin{array}{l}c \\
\vdots \\
0 \\
0 \\
\vdots \\
\vdots \\
\vdots \\
a \\
a \\
a\end{array}$ & 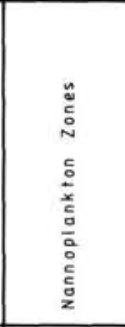 \\
\hline $27 x-1,116-117 \mathrm{~cm}$ & & $R$ & $F$ & & & & & & $R$ & & $\mathrm{~F}$ & & & & & & & & & $\mathrm{~F}$ & $\mathrm{~F}$ & & & & & & PIM & \multirow{2}{*}{$(\sim \mathrm{NN} 6 / 7$} \\
\hline $27 x, c c, 12-13 \mathrm{~cm}$ & & $R$ & $F$ & & & & & & & & $\mathrm{~F}$ & ct. & & & & & & $R$ & & C & $F$ & & & & & & PIM & \\
\hline $28 \mathrm{x}-1,56-57 \mathrm{~cm}$ & & c & $R$ & & & $R$ & & & & & $R$ & & & & & & & & & $A$ & $A$ & $\mathrm{~F}$ & & & & & M & \multirow{4}{*}{$(\sim N N \quad 6)$} \\
\hline $28 \times, c c$ & & C & $\mathrm{F}$ & & & & & & $R$ & $\mathrm{R}$ & $R$ & & & & & & & & & c & $c$ & $\mathrm{~F}$ & & & & & PIM & \\
\hline $29 x-1,17-18 \mathrm{~cm}$ & & $R$ & $R$ & & & & & & & $\mathrm{~F}$ & $R$ & & cf & $\mathrm{F}$ & & & & & & c & c & $\mathrm{F}$ & & & & & PIM & \\
\hline $29 x, c c$ & & $R$ & & & & & & & & & & & & & $R$ & & & & & $c$ & $c$ & $R$ & & & & & PIM & \\
\hline $30 \mathrm{x}-1,112-113 \mathrm{~cm}$ & $R$ & $F$ & $F$ & & & & & $R$ & & & $R$ & & & & & & & $R$ & $R$ & $c$ & $c$ & $\mathrm{~F}$ & & & & & $M$ & \multirow{2}{*}{ NN 8} \\
\hline $30 x, c c$ & $\mathrm{R}$ & $R$ & $F$ & & & & & & & $R$ & & & & & & & & $F$ & & c & $F$ & $\mathrm{~F}$ & & & & & M & \\
\hline $31 x-2,10-11 \mathrm{~cm}$ & & $\mathrm{~F}$ & C & & & & $R$ & & & $\mathrm{R}$ & $R$ & & & ct. & & & & $\mathrm{F}$ & & C & C & $\mathrm{F}$ & & $\mathrm{R}$ & & & PIM & \multirow{3}{*}{$(\sim N N \quad 6)$} \\
\hline $31 x, c e$ & & $F$ & $R$ & & & & & & & cf. & $R$ & & & ct. & & & & $R$ & & $c$ & $c$ & $\mathrm{~F}$ & & & & & $M$ & \\
\hline $32 x, c c$ & & & $R$ & & & & & & & & & & & & & & & & & $\mathrm{R}$ & $R$ & & & & & & $P$ & \\
\hline $33 \times, c c$ & & $R$ & $\mathrm{~F}$ & $R$ & & & & & & & $R$ & & & $\mathrm{cf}$ & & & & $R$ & & c & $C$ & $F$ & & & & & PIM & NN 6 \\
\hline cores $34 x$ to $38 x$ & \multicolumn{27}{|c|}{ bar ren } & $?$ \\
\hline $39 x-2,106-107 \mathrm{~cm}$ & & $\mathrm{~F}$ & $\mathrm{~F}$ & $\mathrm{~F}$ & C & & & & & & $R$ & & & & & & & & & $c$ & $C$ & $R$ & & & & & M & N \\
\hline $39 \times, c 6$ & & $R$ & $\mathrm{~F}$ & $\mathrm{~F}$ & $c$ & & & & & & $\mathrm{~F}$ & & & & $R$ & & & & & $\mathrm{~F}$ & $C$ & $R$ & & & & & PIM & NN \\
\hline $40 \mathrm{x}-1,104-105 \mathrm{~cm}$ & & & $F$ & & $F$ & & & $R$ & & & $R$ & & & & $R$ & $R$ & & $\mathrm{~F}$ & & & c & $R$ & $R$ & $R$ & & & PIM & \multirow{4}{*}{ NN 5} \\
\hline $40 x-3,121-122 \mathrm{~cm}$ & & $R$ & $\mathrm{~F}$ & & $R$ & & & & & & $R$ & & & $R$ & $\mathrm{R}$ & $R$ & & $R$ & & $\mathrm{R}$ & C & & $R$ & & & & PIM & \\
\hline $40 \times, c c$ & & $\mathrm{~F}$ & C & $\mathrm{F}$ & $\mathrm{F}$ & & & & & & $F$ & & & & & $R$ & & $\mathrm{~F}$ & & $F$ & c & & $R$ & & & & $P / M$ & \\
\hline $41 x, c t$ & & C & $\mathrm{F}$ & $\mathrm{F}$ & $\mathrm{F}$ & & & & & $\mathrm{R}$ & $\mathrm{F}$ & & & $R$ & $F$ & & & c & & $\mathrm{F}$ & C & & $\mathrm{R}$ & & & & PIM & \\
\hline $42 x, c 0$ & & & & & & & & & ct. & & $c$ & & & $\mathrm{~F}$ & $\mathrm{~F}$ & & & & & & & & & & & 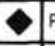 & P/M & $?$ \\
\hline $43 x, c c$ & & $R$ & $F$ & $R$ & & & & & & & $\mathrm{~F}$ & & & $\mathrm{~F}$ & $\mathrm{~F}$ & $R$ & & $R$ & & $F$ & & & $R$ & & & $\Delta$ & PIM & \multirow{2}{*}{ N N 5} \\
\hline $44 x-4,115-116 \mathrm{~cm}$ & & C & $F$ & \begin{tabular}{|l|l|}
$R$ \\
\end{tabular} & $R$ & & & & & $\mathrm{R}$ & $\mathrm{F}$ & & & $R$ & $\mathrm{~F}$ & $R$ & & $\mathrm{~F}$ & & & C & $F$ & $\mathrm{~F}$ & & & & PIM & \\
\hline $64 x, 65$ & \multirow{2}{*}{\multicolumn{27}{|c|}{ barren }} & \multirow{2}{*}{$?$} \\
\hline $45 \mathrm{x}-2,112-113 \mathrm{~cm}$ & & & & & & & & & & & & & & & & & & & & & & & & & & & & \\
\hline $45 x, c 6$ & & $R$ & $R$ & & $R$ & & & & & & $\mathrm{~F}$ & & & $\mathrm{~F}$ & $R$ & & & $R$ & & & & & $R$ & & & $\Delta$ & P/M & NN 5 \\
\hline
\end{tabular}

contain the nannoplankton assemblage of Zone NP13, with the exception of Cores 112-688E-40R and -41R (716.6-735.5 mbsf), which are barren of calcareous nannoplankton.

Based on calcareous nannoplankton and silicoflagellates (Martini, this volume), sedimentation rates at Site 688 are increasing downward from approximately $98 \mathrm{~m} / \mathrm{m} . \mathrm{y}$. in the late Quaternary (0-46 mbsf), to approximately $135 \mathrm{~m} / \mathrm{m}$.y. in the late early Quaternary (46-179 mbsf), and to approximately $350 \mathrm{~m} / \mathrm{m}$.y. in the earliest Quaternary (179-340 mbsf), if the lowest occurrence of Mesocena quadrangula at this site really is near the Pliocene/Pleistocene boundary. Sedimentation rates for the upper part of Hole $688 \mathrm{E}$ down to Core 112$688 \mathrm{E}-11 \mathrm{R}$ at present cannot be evaluated because of suspected hiatuses and the, as yet unknown, time involved. In the middle Miocene ( 450 to 528 mbsf), sedimentation rates may exceed $43 \mathrm{~m} / \mathrm{m}$.y., based on the occurrence of nannoplankton Zone NN6 in this interval. In the lower Miocene (545-593 mbsf), a rate of at least $9.4 \mathrm{~m} / \mathrm{m} . \mathrm{y}$. is indicated by the calcareous nannoplankton, but this may be considerably higher because the interval between Cores 112-688E-22R and $-26 \mathrm{R}$ may represent only part of nannoplankton Zone
NN1/NN2. The middle Eocene is represented by nannoplankton Zone NP16 in Cores 112-688E-27R to -35R, and a sedimentation rate of more than $47.5 \mathrm{~m} / \mathrm{m} . \mathrm{y}$. may be expected between 593 and $678 \mathrm{mbsf}$. In the lower Eocene, a sedimentation rate up to $125 \mathrm{~m} / \mathrm{m}$.y. may be calculated (678-775 mbsf). Note that the sedimentation rates are not adjusted to dipping values.

\section{DISCUSSION}

Calcareous nannoplankton in the Quaternary and late Neogene upwelling areas off Peru, which were sampled in a north-south transect (Sites $684,679,687,686$ ) between $9^{\circ} \mathrm{S}$ and $13^{\circ} 30^{\prime} \mathrm{S}$ at a water depth of approximately $400 \mathrm{~m}$ and in a west-east transect at $11^{\circ} \mathrm{S}$ (Site 679 at a water depth of $450 \mathrm{~m}$, Site 680 at $253 \mathrm{~m}$, and Site 681 at $151 \mathrm{~m}$ ) exhibit a low diversity in species. The more common ones include Gephyrocapsa oceanica, Helicosphaera carteri, in the youngest sediments, Ericsonia huxleyi (PI. 1, Fig. 5), and in levels older than late Pliocene, Reticulofenestra pseudoumbilica. Scattered blooms, especially of Gephyrocapsa oceanica (PI. 1, Fig. 4) and smaller Gephyrocapsa species, were noted. These were 
Table 7. Distribution of calcareous nannoplankton in selected samples from Hole $684 \mathrm{~A}$ and indications of standard nannoplankton zones.

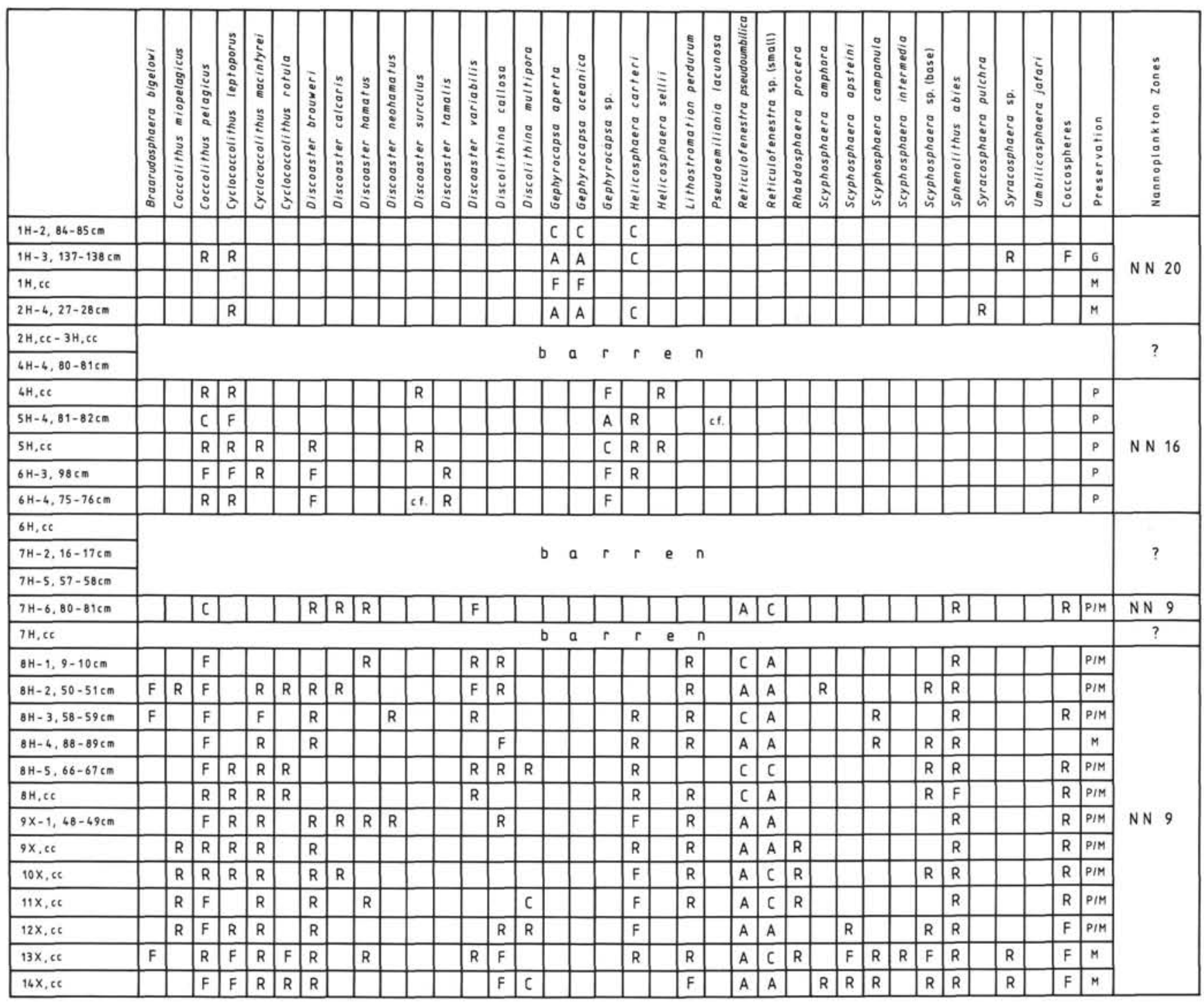

Note: $\mathrm{R}=$ rare, $\mathrm{F}=$ few $\mathrm{C}=$ common, $\mathrm{A}=$ abundant. Preservation: $\mathrm{P}=$ poor, $\mathrm{M}=$ moderate, $\mathrm{G}=$ good.

sometimes associated with abundant Helicosphaera carteri (Pl. 1, Figs. 1-3, 6). Only once was a mass occurrence of Pseudoemiliania lacunosa found (Sample 112-683A-9H-5, 2 $\mathrm{cm})$, whereas scattered blooms of Reticulofenestra pseudoumbilica were encountered in the late Miocene and early Pliocene sequences. Coccolithus pelagicus, indicating cooler water masses, is rare or missing in the Quaternary sediments off Peru, with the exception of Sites 679, 682, and 688 , where it was found to be frequent in several levels (Tables 2, 5, and 12). Generally, only moderate preservation of calcareous nannoplankton in areas of upwelling is seen. With increasing abundance of dolomite rhombs, preservation gets poorer, which leads to samples in which the calcareous nannoplankton seems locally dissolved. In addition, levels having heavy production of the siliceous groups exhibit a depletion of calcareous nannoplankton.

The Scyphosphaera/Discolithina assemblages of early late Miocene age at Site 684, mentioned in the site summaries, are of special interest, as nearly identical assemblages were reported from Gabon on the west coast of Africa (Martini,
1969). In both cases, the assemblages include Lithostromation perdurum and few Braarudosphaera bigelowi. Scyphosphaera species are frequently found in warm waters and exhibit an increase in diversity from the middle Miocene onward (Jafar, 1975; Rade, 1975). At Site 684, Braarudosphaera bigelowi occurs in two levels: Cores $112-684 \mathrm{~A}-8 \mathrm{H}$ and $-684 \mathrm{~B}-8 \mathrm{H}$ and Cores 112-684A-13X and -684B-13X, indicating nearshore and shallow-water conditions in early late Miocene time (calcareous nannoplankton Zone NN19) for this site. The presence of frequent Coccolithus pelagicus during this time may be related to the ancient cold Humboldt Current offshore.

Hiatuses were found frequently, and are discussed for the Neogene and Quaternary in detail by Schrader and Martini (Suess, von Huene, et al., 1988), as these are based mostly on several fossil groups to obtain sufficient data. In the Paleogene interval, hiatuses were detected predominantly using calcareous nannoplankton. The most important hiatus occurred in the late Eocene and was noted at all sites that reach the corresponding depth. At the northern Site 683, a hiatus includes most of nannoplankton Zone NP17, up to part of Zone NN5 
Table 8. Distribution of calcareous nannoplankton in selected samples from Hole $685 \mathrm{~A}$ and indication of standard nannoplankton zones.

\begin{tabular}{|c|c|c|c|c|c|c|c|c|c|c|c|c|c|c|c|c|c|}
\hline & $\begin{array}{l}n \\
\vdots \\
\vdots \\
\vdots \\
\vdots \\
\vdots \\
\vdots \\
\vdots \\
\vdots \\
\vdots \\
\vdots \\
\vdots \\
\vdots \\
\vdots\end{array}$ & 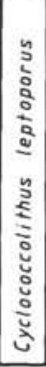 & \begin{tabular}{|c|} 
\\
$n$ \\
$\vdots$ \\
$\vdots$ \\
$\vdots$ \\
0 \\
$\vdots$ \\
$\vdots$ \\
$\vdots$ \\
$\vdots$ \\
$\vdots$ \\
$\vdots$ \\
$\vdots$ \\
\end{tabular} & 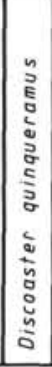 & 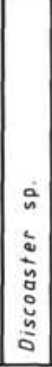 & $\begin{array}{l}0 \\
\vdots \\
\vdots \\
0 \\
\vdots \\
\vdots \\
\vdots \\
\vdots \\
\vdots \\
\vdots \\
\text { ลे } \\
\vdots \\
\vdots\end{array}$ & $\begin{array}{l}\text { : } \\
\vdots \\
\vdots \\
\vdots \\
\vdots \\
\vdots \\
\vdots \\
\vdots \\
\vdots \\
\vdots \\
\vdots \\
\vdots \\
\vdots \\
\vdots\end{array}$ & 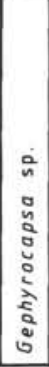 & \begin{tabular}{|c|} 
\\
$z$ \\
$\vdots$ \\
$\vdots$ \\
$\vdots$ \\
$\vdots$ \\
0 \\
$\vdots$ \\
$\vdots$ \\
$\vdots$ \\
$\vdots$ \\
$\vdots$ \\
$\vdots$ \\
$\vdots$ \\
$\vdots$ \\
\\
\end{tabular} & 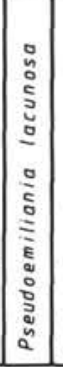 & 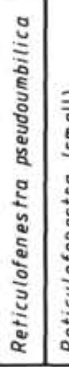 & 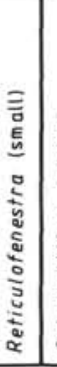 & 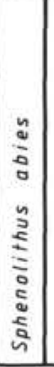 & 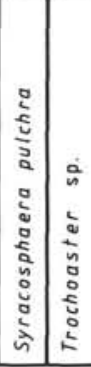 & 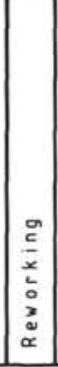 & 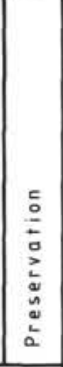 & 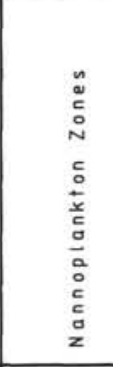 \\
\hline $1 \mathrm{H}, \mathrm{CC}$ & \multicolumn{16}{|c|}{ b a r r e n } & $?$ \\
\hline $3 \mathrm{H}-2,19-20 \mathrm{~cm}$ & $R$ & $R$ & & & & A & C & & $C$ & & & & & $R$ & & G/M & NN 20 \\
\hline $3 \mathrm{H}, \mathrm{CC}$ & \multicolumn{16}{|c|}{ barren } & $?$ \\
\hline $4 \mathrm{H}, \mathrm{CC}$ & $\mathrm{R}$ & $R$ & & & & C & $C$ & & $\mathrm{~F}$ & & & & & & & M & NN 20 \\
\hline $5 x, c c$ & \multicolumn{16}{|c|}{ barren } & $?$ \\
\hline $6 x, c e$ & & & & & & $\mathrm{~F}$ & & & & & & & & & & $M$ & \multirow{2}{*}{ NN 20} \\
\hline $7 x-2,99-100 \mathrm{~cm}$ & $R$ & . & & & & 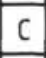 & $R$ & & $\mathrm{~F}$ & & & & & & & $M$ & \\
\hline $8 x-4,24-25 \mathrm{~cm}$ & $R$ & $\mathrm{~F}$ & & & & $A$ & $\mathrm{~F}$ & & $\mathrm{~F}$ & $\mathrm{R}$ & & & & & & $M$ & \multirow{5}{*}{ NN 19} \\
\hline $9 x, c e$ & & & & & & $C$ & & & ct. & & & & & & & M & \\
\hline $10 \mathrm{x}-4,98-99 \mathrm{~cm}$ & & $\mathrm{R}$ & & & & $c$ & $R$ & & & & & & & & & $M$ & \\
\hline $11 x, c c$ & $\mathrm{R}$ & & & & & C & $R$ & & $\mathrm{R}$ & & & & & & & PIM & \\
\hline $12 \mathrm{x}-2,98-99 \mathrm{~cm}$ & & & & & & $C$ & $R$ & & $R$ & $R$ & & & & & & & \\
\hline $13 x, c c$ & \multicolumn{16}{|c|}{ barren } & $?$ \\
\hline $14 x, c c$ & & & & & & $\mathrm{~F}$ & & & & & & & & & & PIM & \multirow{3}{*}{$\sim \mathrm{NN} 19$} \\
\hline $15 x, c c$ & $R$ & $R$ & & & & $\mathrm{C}$ & $\mathrm{F}$ & & $R$ & & & & & & & $P / M$ & \\
\hline $16 \times, c c$ & & $\mathrm{R}$ & & & & $C$ & $F$ & & $F$ & & & & & & & PIM & \\
\hline $17 x, c c$ & \multirow{2}{*}{\multicolumn{16}{|c|}{ batren }} & \multirow{2}{*}{$?$} \\
\hline $18 X, c c$ & & & & & & & & & & & & & & & & & \\
\hline $19 \times, c c$ & $R$ & & & & & $R$ & & & & & & & & & & PIM & $\sim$ NN 19 \\
\hline $20 x, c e$ & \multicolumn{16}{|c|}{ bar ren } & $?$ \\
\hline $21 X, c c$ & & & & & & $\mathrm{~F}$ & $R$ & & $\mathrm{R}$ & & & & & & & $p$ & $\sim \mathrm{NN} 19$ \\
\hline $22 x, c c$ & \multicolumn{16}{|c|}{ barren } & $?$ \\
\hline $23 x, c e$ & & $\mathrm{R}$ & cf. & $\mathrm{R}$ & $R$ & & & $\mathrm{R}$ & & & $\mathrm{F}$ & & $R$ & $R$ & & M & \multirow{3}{*}{ N N 11} \\
\hline $25 \mathrm{x}-1,3 \mathrm{~cm}$ & $R$ & & & $\mathrm{~F}$ & & & & & & & $R$ & $\mathrm{~F}$ & $R$ & & & $M$ & \\
\hline $25 \times, c 0$ & & & & $R$ & & & & & & & & & & & & PIM & \\
\hline $26 x, c c$ & & & $\mathrm{R}$ & & & & & & & & $R$ & $R$ & & & & PIM & N N 10 \\
\hline cores $27 x$ to $37 x$ & \multicolumn{16}{|c|}{ barren } & $?$ \\
\hline $38 \mathrm{x}-1,36 \mathrm{~cm}$ & $R$ & & $\mathrm{R}$ & & & & & & & & $\mathrm{R}$ & $C$ & $R$ & & & PIM & \multirow{2}{*}{ NN 10} \\
\hline $38 \times, c c$ & & & & & & & & & & & $\mathrm{~F} / \mathrm{C}$ & C 5 & ct. & & & $P$ & \\
\hline cores $39 x$ to $43 x$ & \multicolumn{16}{|c|}{ barren } & $?$ \\
\hline Core $44 x$ & & & & & & & & & & & & & & & $\begin{array}{l}M \\
E\end{array}$ & $M$ & $?$ \\
\hline Cores $45 x$ to $47 x$ & \multicolumn{16}{|c|}{ barren } & $?$ \\
\hline $48 \mathrm{x}-1,27 \mathrm{~cm}$ & $R$ & & & & & & & & $\mathrm{R}$ & & $R$ & C & & & & $\mathrm{P}$ & \multirow{2}{*}{$?$} \\
\hline $48 \mathrm{x}, \mathrm{cc}, 23 \mathrm{~cm}$ & & & & & & & & & & & $R$ & $R$ & & & & $P$ & \\
\hline Core $49 x$ & \multicolumn{16}{|c|}{ barren } & $?$ \\
\hline Core $50 x$ & & & & & & & & & & & & & & & $\begin{array}{l}M \\
E\end{array}$ & $M$ & \\
\hline Core $51 x$ & \multicolumn{16}{|c|}{ b a r r en } & $?$ \\
\hline
\end{tabular}

Note: $\mathrm{R}=$ rare, $\mathrm{F}=$ few, $\mathrm{C}=$ common, $\mathrm{A}=$ abundant. Preservation: $\mathrm{P}=$ poor, $\mathrm{M}=$ moderate, $\mathrm{G}=$ good. Reworking: $\mathrm{C}=$ Cretaceous, $\mathrm{E}=$ Eocene, $\mathrm{M}=$ Miocene. 
Table 9. Stratigraphic position of calcareous nannoplankton assemblages in selected clasts found in slumped material of late Miocene age in Cores 112-685A-44R and -50R.

\begin{tabular}{|c|c|c|c|}
\hline $\begin{array}{l}\text { Core, section, interval } \\
(\mathrm{cm})\end{array}$ & & Zonation & \\
\hline $\begin{aligned} 112-685 \mathrm{~A}-44 \mathrm{R}-1,28 \\
-2,6 \\
-2,63 \\
-2,82 \\
-2,127 \\
-3,4 \\
-\mathrm{CC}, 16-18 \\
-\mathrm{CC}, 27\end{aligned}$ & $\begin{array}{l}\text { Lower Miocene }(\mathrm{NN} 1 / \mathrm{NN} 2) \\
\text { Lower Miocene } \\
\text { Lower Miocene }(\mathrm{NN} 1 / \mathrm{NN} 2) \\
\text { Lower Miocene }(\mathrm{NN} 1 / \mathrm{NN} 2) \\
\text { Lower Miocene? } \\
\text { Lower Miocene }(\mathrm{NN} 4) \\
\text { Lower Miocene }(\mathrm{NN} 1 / \mathrm{NN} 2)\end{array}$ & $\begin{array}{l}\text { and reworked Eocene } \\
\text { and reworked Eocene } \\
\text { and reworked Eocene } \\
\text { and reworked Eocene }\end{array}$ & Eocene (NP17/NP20) \\
\hline $\begin{aligned} 112-685 \mathrm{~A}-50 \mathrm{R}-1,15 \\
-1,53 \\
-1,73 \\
-1,81,5 \\
-\mathrm{CC}, 11 \\
-\mathrm{CC}, 24\end{aligned}$ & $\begin{array}{l}\text { Lower Miocene? } \\
\text { Lower Miocene }(\mathrm{NN} 1 / \mathrm{NN} 2) \\
\text { Lower Miocene? } \\
\text { Lower Miocene }(\sim \mathrm{NN} 2)\end{array}$ & & $\begin{array}{l}\text { Eocene (NP17/NP20) } \\
\text { Eocene (NP17/NP20) }\end{array}$ \\
\hline
\end{tabular}

Table 10. Distribution of calcareous nannoplankton in selected samples from Holes 686A and 686B and indication of standard nannoplankton zones.

\begin{tabular}{|c|c|c|c|c|c|c|c|c|c|c|c|}
\hline & 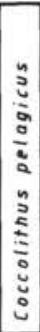 & 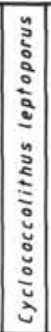 & 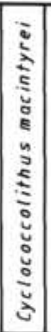 & 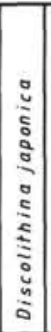 & $\begin{array}{l}0 \\
\vdots \\
\vdots \\
\vdots \\
\vdots \\
\vdots \\
\vdots \\
\vdots \\
\vdots \\
\vdots \\
\vdots \\
\vdots \\
\vdots\end{array}$ & $\begin{array}{l}0 \\
\vdots \\
\vdots \\
\vdots \\
\vdots \\
\vdots \\
\check{~} \\
\vdots \\
\vdots \\
\vdots \\
\vdots \\
\vdots \\
\vdots\end{array}$ & 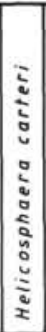 & $\begin{array}{c}\vdots \\
\vdots \\
\vdots \\
\vdots \\
\vdots \\
\vdots \\
\vdots \\
\vdots \\
\vdots \\
\vdots \\
\vdots \\
\vdots \\
\Sigma \\
\end{array}$ & 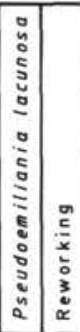 & 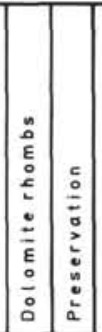 & 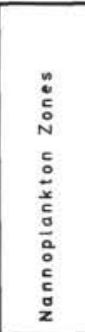 \\
\hline A Cores $1 \mathrm{H}$ to $7 \mathrm{H}$ & \multicolumn{10}{|c|}{$b a r+e n$} & $?$ \\
\hline $8 \mathrm{H}-2,8-9 \mathrm{~cm}$ & & & & & C & $\mathrm{F}$ & $R$ & & & M & NN20 \\
\hline Core $9 x$ & \multicolumn{10}{|c|}{ barren } & $?$ \\
\hline $10 x-2,68-69 \mathrm{~cm}$ & $R$ & $\mathrm{~F}$ & & & C & $F$ & & & \begin{tabular}{|l|l|}
$R$ & $M$ \\
\end{tabular} & $M$ & NN19 \\
\hline Core $11 x$ & \multicolumn{10}{|c|}{ barien } & $?$ \\
\hline $12 x-2,80-81 \mathrm{~cm}$ & $R$ & $R$ & & & C & C & $R$ & & M & M & NN19 \\
\hline Cores $13 x$ to $15 x$ & \multicolumn{10}{|c|}{ barren } & $?$ \\
\hline $16 \mathrm{x}-2,31-32 \mathrm{~cm}$ & $R$ & $R$ & & & $F$ & \begin{tabular}{|l|}
$R$ \\
\end{tabular} & & & & $M$ & \multirow{7}{*}{ NN19 } \\
\hline $17 x-6,93-94 \mathrm{~cm}$ & $\mathrm{R}$ & & & & $\mathrm{F}$ & $R$ & & & & $\mathrm{P} / \mathrm{M}$ & \\
\hline $18 \mathrm{X}, \mathrm{cc}$ & $R$ & $R$ & & & $\mathrm{R}$ & & & & M & $P / M$ & \\
\hline $19 x, c c$ & & & $R$ & ct. & $F$ & $R$ & & & E & P/M & \\
\hline $20 \mathrm{X}, \mathrm{cc}$ & & $R$ & & & $R$ & & & & $E$ & $P$ & \\
\hline $21 x, c c$ & $R$ & & & & $R$ & & R & & \begin{tabular}{l|l}
$R$ & $M$ \\
$E$
\end{tabular} & $P / M$ & \\
\hline $22 x, c c$ & $R$ & $R$ & $R$ & & $R$ & & $R$ & & \begin{tabular}{l|l} 
& $M$ \\
$E$
\end{tabular} & $P / M$ & \\
\hline Core $23 x$ & \multirow{2}{*}{\multicolumn{10}{|c|}{ baren }} & \multirow{2}{*}{$?$} \\
\hline$B$ core $26 x$ & & & & & & & & & & & \\
\hline $25 x, c c$ & & $R$ & $R$ & & $R$ & & $R$ & & $\begin{array}{ll}R & M \\
\end{array}$ & $P / M$ & NN 19 \\
\hline $26 x, c c$ & \multicolumn{10}{|c|}{ barren } & $?$ \\
\hline $27 x, c c$ & $R$ & & & & ct. & & & & M & $P$ & \multirow{4}{*}{$?$} \\
\hline $28 \times-4,96-95 \mathrm{~cm}$ & $R$ & & & & ct. & & & & M & $\mathbf{P}$ & \\
\hline $29 \times, c c$ & $R$ & & & & ct. & & $R$ & & M & $P$ & \\
\hline $30 \mathrm{x}-2,89-90 \mathrm{~cm}$ & & & & & ct. & & & $R$ & $\frac{M}{E}$ & $P$ & \\
\hline core $31 x$ & \multicolumn{10}{|c|}{ barr.n } & $?$ \\
\hline $32 \times-2,59-60 \mathrm{~cm}$ & & & & & ct. & & & & M & $P$ & $?$ \\
\hline $32 x, c c$ & \multicolumn{10}{|c|}{ baren } & $?$ \\
\hline
\end{tabular}

Note: $\mathrm{R}=$ rare, $\mathrm{F}=$ few, $\mathrm{C}=$ common, $\mathrm{A}=$ abundant. Preservation: $\mathrm{P}=$ poor, $\mathrm{M}=$ moderate, $\mathrm{G}=$ good. Reworking: $\mathrm{C}=$ Cretaceous, $\mathrm{E}=$ Eocene, $\mathrm{M}=$ Miocene. (late middle Eocene to early middle Miocene, approximately 26 m.y). At the southern Site 688, the missing interval included part of nannoplankton Zone NP16, to a level within Zones NN1/NN2 (late middle Eocene to early Miocene, approximately $21.5 \mathrm{~m} . \mathrm{y}$.). At Site 682 , the hiatus is between the upper part of Zone NP16 and Zone NP21 (late middle Eocene to early Oligocene, approximately $8 \mathrm{~m} . \mathrm{y}$.). Another hiatus is suspected in the Oligocene at this site, but because of poor recovery and a barren interval cannot be ascertained. This major hiatus also was observed during DSDP Leg 90 at Site 588 on the Lord Howe Rise (Martini, 1986), where it includes part of the combined nannoplankton Zones NP15/ NP16 to Zone NP24 (middle Eocene to early late Oligocene, approximately 19 m.y.). Similar hiatuses were reported by Edwards (1973) from DSDP Sites 206, 207, and 208.

Kennett and von der Borch (1986) discussed the causes for this major regional hiatus in the southwest Pacific and related it to erosional bottom currents flowing northward. These probably were triggered by the separation of Antarctica and Australia about $50 \mathrm{~m}$.y. ago and by the newly developed current system in the southern Pacific. This may also apply to the Leg 112 sites off Peru. Another possibility is the lowering of sea level at the end of the middle and late Eocene, as shown by the Vail curve in Harland et al. (1982). A large-scale erosional change was already announced in the highest levels of the preserved middle Eocene sequences by the presence of reworked Cretaceous nannoplankton at Sites 682 and 688, unknown in the lower middle Eocene sequence, which exhibits an increase in abundance in the basal Oligocene of Site 682 . In addition, the calcareous nannoplankton in the middle Eocene seem to indicate a shallow depositional level for these sites at that particular time.

\section{ACKNOWLEDGMENTS}

My thanks to the Deutsche Forschungsgemeinschaft (Bonn) for supporting this study. SEM photographs were taken by J. Tochtenhagen with a Stereoscan Mark 2, which was provided to the Geologisch-Paläontologisches Institut der Universität Frankfurt am Main by the Volkswagenstiftung. I also acknowledge suggestions made by the reviewers, L. M. Bybell (U.S. Geol. Survey) and S. Gartner (Texas A\&M Univ.).

\section{REFERENCES}

Backman, J., and Shackleton, N. J., 1983. Quantitative biochronology of Pliocene and early Pleistocene calcareous nannoplankton from the Atlantic, Indian and Pacific oceans. Mar. Micropaleontol., 8:141-170. 
Berggren, W. A., Kent, D. V., Flynn, J. J., and Van Couvering, J. A., 1985. Cenozoic geochronology. Geol. Soc. Am. Bull., 96:1407-1418.

Edwards, A. R., 1973. Southwest Pacific regional unconformities encountered during Leg 21. In Burns, R. E., Andrews, J. E., et al., Init. Repts. DSDP, 21: Washington (U.S. Govt. Printing Office), 701-720.

Harland, W. B., Cox, A. V., Llewellyn, P. G., Pickton, C.A.G., Smith, A. G., and Walters, R., 1982. A Geologic Time Scale: Cambridge (Cambridge Earth Sci. Ser.), 1-131.

Jafar, S. A., 1975. Calcareous nannoplankton from the Miocene of Rotti, Indonesia. Verhand. Konink. Nederl. Akad. Wetenschapmen, Afd. Natuurkunde, 28:1-99.

Kennett, J. P, and von der Borch, C. C., 1986. Southwest Pacific Cenozoic Paleoceanography. In Kennett, J. P., von der Borch, C. C., et al., Init. Repts. DSDP, 90: Washington (U.S. Govt. Printing Office), 1493-1517.

Martini, E., 1969. Nannoplankton aus dem Miozän von Gabon (Westafrika). Neues Jahr. Geol. Paläontol., Abh., 132:285-300. 1971. Standard Tertiary and Quaternary calcareous nannoplanton zonation. In Farinacci, A. (Ed.), 2nd Planktonic Conf. Roma, 1970, Vol. 2: Rome (Editioni Tecnosciencia), 739-785.

1979. Calcareous nannoplankton and silicoflagellate biostratigraphy at Reykjanes Ridge, northeastern North Atlantic (DSDP Leg 49, Sites 407 and 409). In Luyendyk, B. P., Cann, J. R., et al., Init. Repts. DSDP, 49: Washington (U.S. Govt. Printing Office), 533-549

1986. Paleogene calcareous nannoplankton from the southwestern Pacific Ocean, Deep Sea Drilling Project, Leg 90. In Kennett, J. P., von der Borch, C. C., et al., Init. Repts. DSDP, 90: Washington (U.S. Govt. Printing Office), 747-761.

Martini, E., Fahlbusch, V., and Hagn, H., 1986. The Eocene/ Oligocene boundary and the Latdorfian (lower Oligocene). A statement by the German Subcommission on Tertiary Stratigraphy. Newsl. Stratigr., 17:37-43.

Martini, E., and Müller, C., 1986. Current Tertiary and Quaternary calcareous nannoplankton stratigraphy and correlations. Newsl. Stratigr., 16:99-112.

Müller, C., 1976. Tertiary and Quaternary calcareous nannoplankton in the Norwegian-Greenland Sea, DSDP, Leg 38. In Talwani, M., Udintsev, G., et al., Init. Repts. DSDP, 38: Washington (U.S. Govt. Printing Office), 823-841. 1979. Calcareous nannofossils from the North Atlantic (Leg 48). In Montadert, L., Roberts, D. G., et al., Init. Repts. DSDP, 48: Washington (U.S. Govt. Printing Office), 589-639.

Okada, H., and Bukry, D., 1980. Supplementary modification and introduction of code numbers to the low-latitude coccolith biostratigraphic zonation (Bukry 1973, 1975). Mar. Micropaleontol., $5: 321-325$.

Rade, J., 1975. Scyphosphaera evolutionary trends with special reference to eastern Australia. Micropaleontology, 21:151-164.

Suess, E., von Huene, R., et al., 1988. Proc. ODP, Init. Repts., 112: College Station, TX (Ocean Drilling Program).

Date of initial receipt: 5 July 1988

Date of acceptance: 12 April 1989

Ms 112B-180

\section{APPENDIX}

Eocene to Holocene calcareous nannoplankton from the eastern Pacific off Peru.

Blackites tenuis (Bramlette and Sullivan) Sherwood, 1974

Braarudosphaera bigelowi (Gran and Braarud) Deflandre, 1947

Campylosphaera dela (Bramlette and Sullivan) Hay and Mohler, 1967

Catinaster coalitus Martini and Bramlette, 1963

Ceratolithus rugosus Bukry and Bramlette, 1968

Chiasmolithus altus Bukry and Percival, 1971

Chiasmolithus consuetus (Bramlette and Sullivan) Hay and Mohler, 1967

Chiasmolithus grandis (Bramlette and Riedel) Radomski, 1968
Chiasmolithus solitus (Bramlette and Sullivan) Locker, 1968

Chiphragmalithus cristatus (Martini) Bramlette and Sullivan, 1961

Coccolithus eopelagicus (Bramlette and Riedel) Bramlette and Sullivan, 1961

Coccolithus miopelagicus Bukry, 1971

Coccolithus pelagicus (Wallich) Schiller, 1930

Coronocyclus nitescens (Kamptner) Bramlette and Wilcoxon, 1967

Cribrocentrum reticulatum (Gartner and Smith) Perch-Nielsen, 1971

Cruciplacolithus staurion (Bramlette and Sullivan) Gartner, 1971

Cyclicargolithus abisectus (Müller) Wise, 1973

Cyclicargolithus floridanus (Roth and Hay) Bukry, 1971

Cyclococcolithus formosus Kamptner, 1963

Cyclococcolithus gammation (Bramlette and Sullivan) Sullivan, 1964

Cyclococcolithus leptoporus (Murray and Blackman) Kamptner, 1954 ex 1956

Cyclococcolithus luminis Sullivan, 1965

Cyclococcolithus macintyrei Bukry and Bramlette, 1969

Cyclococcolithus rotula (Kamptner) Kamptner, 1956

Dictyococcites dictyodus (Deflandre and Fert) Martini, 1969

Discoaster barbadiensis Tan Sin Hok, 1927

Discoaster binodosus Martini, 1958

Discoaster brouweri Tan Sin Hok, 1927

Discoaster calcaris Gartner, 1967

Discoaster deflandrei Bramlette and Riedel, 1954

Discoaster distinctus Martini, 1958

Discoaster druggii Bramlette and Wilcoxon, 1967

Discoaster elegans Bramlette and Sullivan, 1961

Discoaster exilis Martini and Bramlette, 1963

Discoaster germanicus Martini, 1958

Discoaster hamatus Martini and Bramlette, 1963

Discoaster kugleri Martini and Bramlette, 1963

Discoaster lodoensis Bramlette and Riedel, 1954

Discoaster neohamatus Brukry and Bramlette, 1969

Discoaster quinqueramus Gartner, 1969

Discoaster saipanensis Bramlette and Riedel, 1954

Discoaster septemradiatus (Klumpp) Martini, 1958

Discoaster sublodoensis Bramlette and Sullivan, 1961

Discoaster surculus Martini and Bramlette, 1963

Discoaster tani Bramlette and Riedel, 1954

Discoaster tamalis Kamptner, 1967

Discoaster variabilis Martini and Bramlette, 1963

Discoaster wemmelensis Achutan and Stradner, 1969

Discoasteroides kuepperi (Stradner) Bramlette and Sullivan, 1961

Discolithina callosa Martini, 1969

Discolithina desueta Müller, 1970

Discolithina distincta (Bramlette and Sullivan) Levin and Joerger, 1967

Discolithina duocava (Bramlette and Sullivan) Perch-Nielsen, 1971

Discolithina enormis Locker, 1967

Discolithina japonica Takayama, 1967

Discolithina multimora (Kamptner ex Deflandre) Martini, 1965

Discolithina plana (Bramlette and Sullivan) Levin, 1965

Ellipsolithus macellus (Bramlette and Sullivan) Sullivan, 1964

Emiliania huxleyi (Lohmann) Hay and Mohler, 1967

Gephyrocapsa aperta Kamptner, 1963

Gephyrocapsa oceanica Kamptner, 1943

Helicosphaera ampliaperta Bramlette and Wilcoxon, 1967

Helicosphaera carteri (Wallich) Kamptner, 1954

Helicosphaera commacta Bramlette and Wilcoxon, 1967

Helicosphaera euphratis Haq, 1966

Helicosphaera lophota (Bramlette and Sullivan) Locker, 1972

Helicosphaera sellii (Bukry and Bramlette) Jafar and Martini, 1975

Helicosphaera seminulum Bramlette and Sullivan, 1961

Isthmolithus recurvus Deflandre, 1954

Koczyia fimbriata (Bramlette and Sullivan) Perch-Nielsen, 1971

Lanternithus minutus Stradner, 1962

Lithostromation perdurum Deflandre, 1942

Markalius inversus (Deflandre) Bramlette and Martini, 1964

Micrantholithus vesper Deflandre, 1950

Neococcolithes dubius (Deflandre) Black, 1967

Pseudoemiliania lacunosa (Kamptner) Gartner, 1969

Reticulofenestra insignita Roth and Hay, 1967 
Reticulofenestra oamaruensis (Deflandre) Stradner and Edwards, 1968

Reticulofenestra pseudoumbilica (Gartner) Gartner, 1969

Reticulofenestra umbilica (Levin) Martini and Ritzkowski, 1968

Reticulofenestra aff. umbilica (Levin) Martini and Ritzkowski, 1968

Rhabdosphaera procera Martini, 1969

Rhabdosphaera rudis Bramlette and Sullivan, 1961

Scyphosphaera amphora Deflandre, 1942

Scyphosphaera apsteini Lohmann, 1902

Scyphosphaera campanula Deflandre, 1942

Scyphosphaera intermedia Deflandre, 1942

Sphenolithus abies Deflandre, 1954

Sphenolithus dissimilis Bukry and Percival, 1971

Sphenolithus furcatolithoides Locker, 1967

Sphenolithus heteromorphus Deflandre, 1953
Sphenolithus moriformis (Brönnimann and Stradner) Bramlette and Wilcoxon, 1967

Sphenolithus orphanknolli Perch-Nielsen, 1971

Sphenolithus predistentus Bramlette and Wilcoxon, 1967

Sphenolithus radians Deflandre, 1954

Svracosphaera pulchra Lohmann, 1902

Transversopontis panarium (Deflandre) Locker, 1967

Transversomontis pulcher (Deflandre) Hay, Mohler and Wade, 1966

Transversopontis pulcheroides (Sullivan) Perch-Nielsen, 1971

Triquetrorhabdulus carinatus Martini, 1965

Trochoaster operosus (Deflandre) Martini and Stradner, 1960

Umbilicosphaera jafari Müller, 1974

Umbilicosphaera mirabilis Lohmann, 1902

Zygrhablithus bijugatus (Deflandre) Deflandre, 1959 
Table 11. Distribution of calcareous nannoplankton in selected samples from Hole 687A and indication of standard nannoplankton zones.

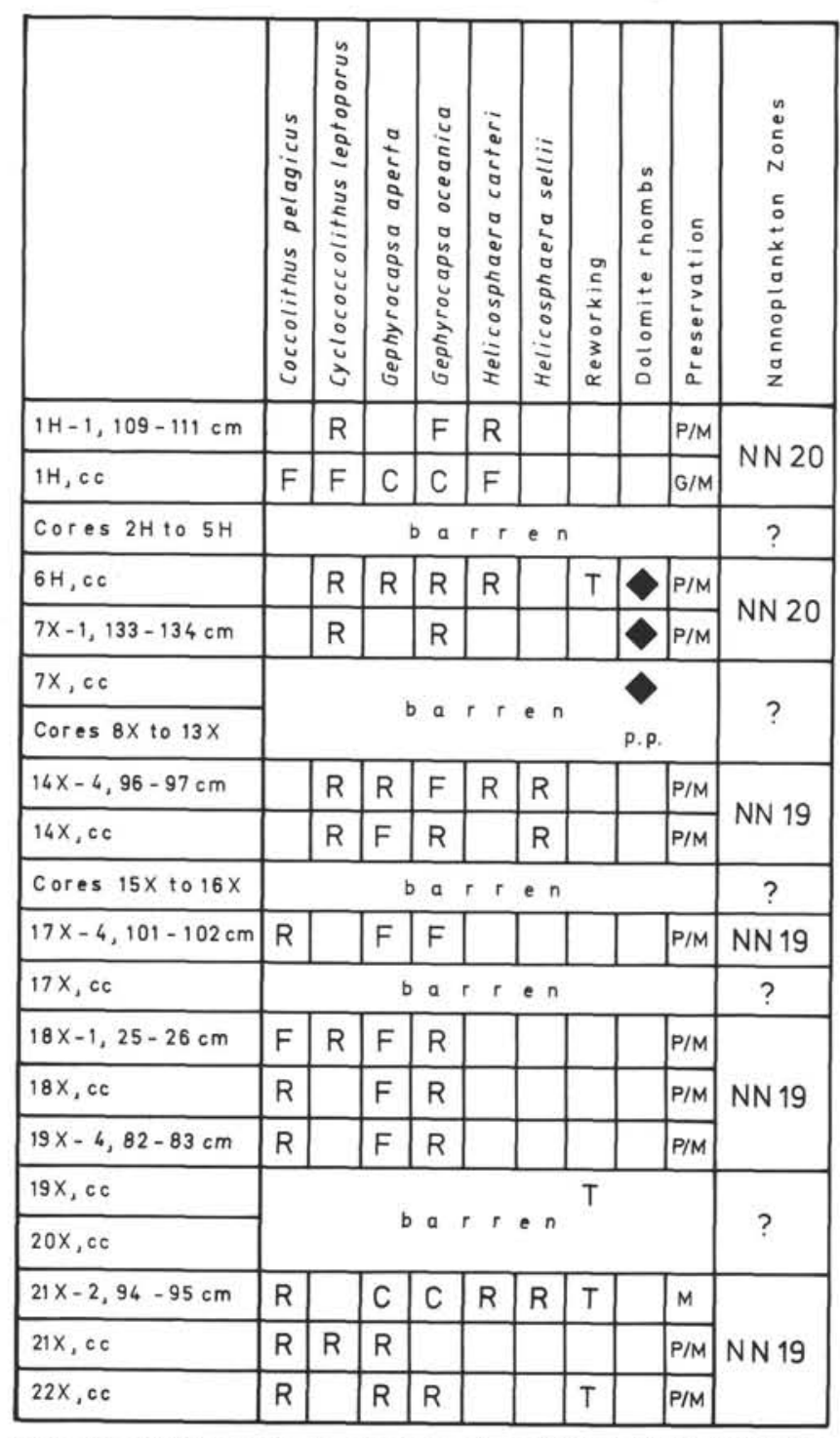

Note: $\mathrm{R}=$ rare, $\mathrm{F}=$ few, $\mathrm{C}=$ common, $\mathrm{A}=$ abundant. Preservation: $\mathrm{P}=$ poor, $\mathrm{M}=$ moderate, $\mathrm{G}=$ good.
Table 12. Distribution of calcareous nanhoplankton in selected samples from Holes $688 \mathrm{~A}$ and $688 \mathrm{E}$ and indication of standard nannoplankton zones.

\begin{tabular}{|c|c|c|c|c|c|c|c|c|c|c|c|c|}
\hline & 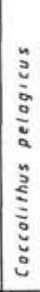 & 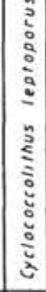 & 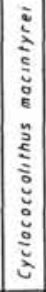 & $\begin{array}{l} \\
\\
\vdots \\
\vdots \\
\vdots \\
\vdots \\
\vdots \\
\vdots \\
\vdots \\
\vdots \\
\vdots \\
\vdots \\
\vdots \\
\vdots \\
\vdots\end{array}$ & 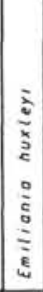 & $\begin{array}{l}0 \\
\vdots \\
\vdots \\
\vdots \\
0 \\
\vdots \\
\vdots \\
\vdots \\
\vdots \\
\vdots \\
\vdots \\
\vdots \\
\vdots\end{array}$ & $\begin{array}{l}0 \\
\vdots \\
\vdots \\
\vdots \\
\vdots \\
\vdots \\
\vdots \\
\vdots \\
\vdots \\
\vdots \\
\vdots \\
\vdots \\
\vdots \\
\vdots \\
\vdots\end{array}$ & $\begin{array}{l}\vdots \\
\vdots \\
\vdots \\
\vdots \\
\vdots \\
\vdots \\
\vdots \\
\vdots \\
\vdots \\
\vdots \\
\vdots \\
\vdots\end{array}$ & 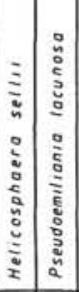 & 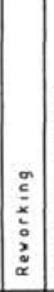 & 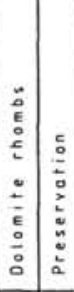 & 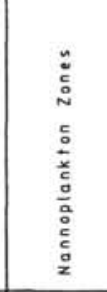 \\
\hline $1 \mathrm{H}-6.91-92 \mathrm{~cm}$ & $F$ & $R$ & & & at & $\mathrm{F}$ & $\mathrm{R}$ & \begin{tabular}{l|l}
$R$ \\
\end{tabular} & & & \begin{tabular}{l|l} 
& $M$ \\
\end{tabular} & NN 21? \\
\hline IH, IC & $R$ & $R$ & & & & $R$ & $R$ & & & & $p$ & \multirow{4}{*}{ NN 20} \\
\hline $2 \mathrm{H}, \mathrm{CH}$ & $F$ & $\mathrm{~F}$ & & & & $c$ & $\mathrm{~F}$ & $c$ & $R$ & M & M & \\
\hline $3 \mathrm{H}, \mathrm{CC}$ & $R$ & $\mathrm{~F}$ & & & & A & C & \begin{tabular}{l|l} 
& 1 \\
\end{tabular} & $R$ & & M & \\
\hline $6 \mathrm{H}, \mathrm{CC}$ & & $\mathrm{F}$ & & & & $c$ & $F$ & $\mathrm{~F}$ & & & $\Delta M$ & \\
\hline SH,CE & $R$ & $\mathrm{~F}$ & & & & $\mathrm{~A}$ & $\mathrm{~F}$ & $\mathrm{~F}$ & c & & \begin{tabular}{l|l} 
& $M$ \\
\end{tabular} & \multirow{6}{*}{ NN 19} \\
\hline SH,CC & $R$ & $R$ & (t) & & & $F$ & $\mathrm{~F}$ & $R$ & & & $\Delta P_{1 M}$ & \\
\hline $7 \mathrm{H.CS}$ & $F$ & $\mathrm{R}$ & & & & $F$ & $\mathrm{~F}$ & $R$ & $\mathrm{R}$ & & \begin{tabular}{l|l} 
& $P, M$ \\
\end{tabular} & \\
\hline $8 \times, c 6$ & $R$ & 1. & . & & & $\mathrm{F}$ & $\mathrm{R}$ & $R$ & & & - PIM & \\
\hline $9 \times, c c$ & & $R$ & (1) & & & $\mathrm{F}$ & $R$ & $\mathrm{R}$ & & $M$ & \begin{tabular}{l|l} 
& $P$ \\
\end{tabular} & \\
\hline $10 x, 46$ & & $\mathrm{R}$ & & & & $F$ & $R$ & & $R$ & & \begin{tabular}{l|l}
$\Delta$ & $p$ \\
\end{tabular} & \\
\hline $11 \times, \mathrm{ce}$ & \multicolumn{11}{|c|}{ barren } & $?$ \\
\hline $12 x, 06$ & & $R$ & & $R$ & & $\mathrm{~F}$ & $R$ & & & & $p$ & \multirow{2}{*}{ NN19 } \\
\hline $13 \times .46$ & $R$ & $F$ & & & & c & $c$ & $F$ & $c$ & & PIM & \\
\hline $16 x, 6 c$ to $16 x, c 6$ & \multicolumn{11}{|c|}{ oorien } & $?$ \\
\hline $17 \times .06$ & & $R$ & & & & $\mathrm{~F}$ & $\mathrm{R}$ & $R$ & & & $P$ & \multirow{6}{*}{ NN19 } \\
\hline $18 \times .66$ & & & & $R$ & & $F$ & $R$ & & & & $P$ & \\
\hline $19 \times, 10$ & & $\mathrm{~F}$ & $R$ & & & c & $c$ & & $R$ & & PIM & \\
\hline $20 \times .16$ & $R$ & $R$ & & & & $F$ & $F$ & & $\mathrm{R}$ & & $P$ & \\
\hline $21 x, 16$ & $\mathrm{R}$ & $R$ & & & & $R$ & $R$ & & & & $P$ & \\
\hline $22 \times, 16$ & $R$ & $R$ & & & & $\mathrm{~F}$ & $F$ & \begin{tabular}{l|l}
$\mathrm{R}$ & \\
\end{tabular} & $R$ & & $P$ & \\
\hline $23 \times .16$ & \multicolumn{11}{|c|}{ borten } & $?$ \\
\hline $26 \times, 06$ & & $R$ & & & & $R$ & $\mathrm{R}$ & & & & $p$ & $?$ \\
\hline $25 x, 06$ to $27 x, 06$ & \multicolumn{11}{|c|}{ borien } & $?$ \\
\hline $28 \times .66$ & R. & $R$ & & & & $R$ & & & & & $P$ & \multirow{2}{*}{$?$} \\
\hline $29 \times .46$ & $\mathrm{~F}$ & & & & & $\mathrm{~F}$ & $R$ & & $R$ & & $P$ & \\
\hline $30 x, c 61031 \times, c 6$ & \multicolumn{11}{|c|}{$00+\ldots n$} & $?$ \\
\hline $32 \times .16$ & $R$ & & & & & $R$ & & & & & $\diamond P$ & \multirow{3}{*}{$?$} \\
\hline $33 \times . c 6$ & $\mathrm{R}$ & & & & & $R$ & & & & & \begin{tabular}{l|l}
$\Delta$ & $p$ \\
\end{tabular} & \\
\hline $36 \times .16$ & & $R$ & & & & $F$ & & & & & \begin{tabular}{l|l}
$\diamond$ & $p$ \\
\end{tabular} & \\
\hline $35 x, 0 c 1037 x, c 5$ & \multicolumn{11}{|c|}{ oor.en } & $?$ \\
\hline
\end{tabular}

Note: $\mathrm{R}=$ rare, $\mathrm{F}=$ few, $\mathrm{C}=$ common, $\mathrm{A}=$ abundant. Preservation: $\mathrm{P}=$ poor, $\mathrm{M}=$ moderate, $\mathrm{G}=$ good. Reworking: $\mathrm{C}=$ Cretaceous, $\mathrm{E}=$ Eocene, $\mathrm{M}=$ Miocene. 
Table 12 (continued).

\begin{tabular}{|c|c|c|c|c|c|c|c|c|c|c|c|c|c|c|c|c|c|c|c|c|c|c|}
\hline & 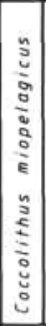 & 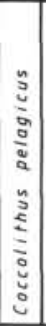 & 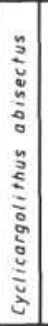 & 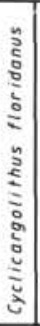 & 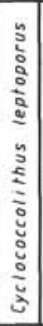 & 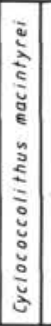 & $\begin{array}{l}0 \\
\vdots \\
\vdots \\
0 \\
n \\
\vdots \\
\vdots \\
\vdots \\
\vdots \\
0 \\
\vdots \\
\vdots \\
\vdots \\
\end{array}$ & $\begin{array}{l} \\
z \\
\vdots \\
\vdots \\
\vdots \\
\vdots \\
\vdots \\
\vdots \\
\vdots \\
\vdots \\
\vdots \\
\vdots \\
\vdots\end{array}$ & $\begin{array}{l}\vdots \\
\vdots \\
\vdots \\
\vdots \\
\vdots \\
\vdots \\
\vdots \\
\vdots \\
\vdots \\
\bar{a} \\
0 \\
\vdots \\
\vdots \\
0\end{array}$ & 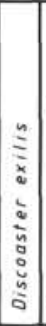 & \begin{tabular}{l|}
$n$ \\
$\vdots$ \\
0 \\
0 \\
$\vdots$ \\
0 \\
$\vdots$ \\
0 \\
$\vdots$ \\
$\vdots$ \\
$\vdots$ \\
$\vdots$ \\
$\vdots$ \\
$\vdots$
\end{tabular} & 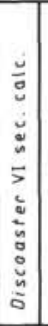 & 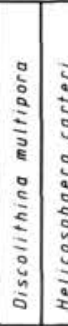 & 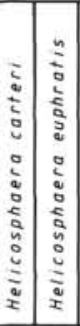 & 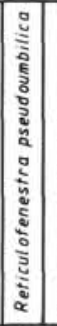 & 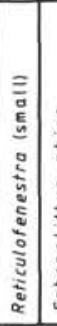 & 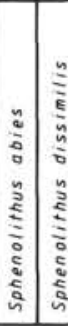 & 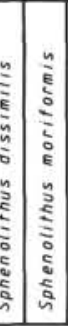 & 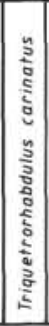 & 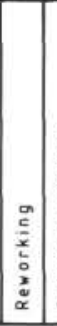 & 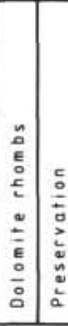 & 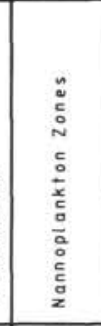 \\
\hline Cores $1 R$ to $11 R$ & & & & & & & & & & & bo & a & ren & & & & & & & & & $?$ \\
\hline $12 \mathrm{R}-2,93-96 \mathrm{~cm}$ & c & $\mathrm{F}$ & $R$ & $R$ & $R$ & & & $R$ & & $R$ & $R$ & $R$ & & $R$ & \begin{tabular}{l|l} 
c & \\
\end{tabular} & \begin{tabular}{l|l} 
C & \\
\end{tabular} & $F$ & & & & PIM & \multirow{6}{*}{ NN 6} \\
\hline $12 R, C S$ & & $R$ & $R$ & & $R$ & & & & & & & $R$ & & & $R$ & $\mathrm{~F}$ & $R$ & & & & P & \\
\hline 13R.CC & & $R$ & & $R$ & $R$ & $R$ & & & & & $R$ & $R$ & & $R$ & $R$ & $\mathrm{~F}$ & & & & & $\Delta P I M$ & \\
\hline $14 R, c c$ & $\mathrm{~F}$ & $\mathrm{~F}$ & & $R$ & & & & & & $R$ & $\mathrm{~F}$ & $\mathrm{~F}$ & & $R$ & $c$ & $c$ & $R$ & & & & PIM & \\
\hline $15 R, C 6$ & $F$ & $F$ & & $R$ & $R$ & & & & & & $R$ & $R$ & & $F$ & C & $\mathrm{c}$ & $R$ & & & & $P / M$ & \\
\hline $16 \mathrm{R}, \mathrm{CC}$ & & & & $R$ & & & & & & if. & & $R$ & & & & $R$ & & & & & $p$ & \\
\hline $17 R, C 6$ & $F$ & $c$ & & $R$ & & $R$ & $R$ & & & $R$ & & & $R$ & $R$ & $C$ & $c$ & $R$ & & & & PIM & \multirow{2}{*}[\mathrm{NN}6]{} \\
\hline $18 R, C C$ & $F$ & $F$ & & & $R$ & $R$ & & & & $F$ & & $F$ & & $R$ & \begin{tabular}{l|l} 
\\
\end{tabular} & \begin{tabular}{l|l}
$c$ & 1 \\
\end{tabular} & $R$ & & & & PIM & \\
\hline $19 R .56$ & \multicolumn{21}{|c|}{ barren } & $?$ \\
\hline $20 \mathrm{R}-1,20-21 \mathrm{~cm}$ & $R$ & $R$ & $R$ & $\mathrm{~F}$ & & & & & & & \begin{tabular}{l|l}
$R$ & \\
\end{tabular} & \begin{tabular}{|l|l|}
$R$ & \\
\end{tabular} & & & \begin{tabular}{l|l} 
\\
\end{tabular} & C & & & & & PII & {$[$ in N 6] } \\
\hline $20 \mathrm{R}, \mathrm{CC}$ & & & & & & & & & & & b a & ar & ren & & & & & & & & & $?$ \\
\hline $21 R, C C$ & $\mathrm{~F}$ & $\mathrm{~F}$ & $R$ & $\mathrm{~F}$ & & & $R$ & & & $R$ & & & & $R$ & \begin{tabular}{l|l} 
& \\
\end{tabular} & c & $F$ & & & & PIM & {$[$ [NN 6$]$} \\
\hline $22 \mathrm{R}-1.2-3 \mathrm{~cm}$ & $\mathrm{~F}$ & $\mathrm{~F}$ & $R$ & $\mathrm{~F}$ & & & & & C & & & $R$ & & & ct. & c & & & & & $\Delta \mid P / 1$ & \multirow{5}{*}{ NN $1 / 2$} \\
\hline $22 R, C C$ & $R$ & $R$ & & & & & & & $F$ & & & $R$ & $R$ & & & $F$ & & & & & - PIM & \\
\hline $23 \mathrm{R}-2,130-131 \mathrm{~cm}$ & $R$ & $F$ & $R$ & C & & & & & $F$ & & & $\mathrm{~F}$ & & & & c & $\bar{R}$ & \begin{tabular}{l|l}
$R$ & $R$ \\
\end{tabular} & & & - PIM & \\
\hline $23 R, C 6$ & $F$ & $\mathrm{~F}$ & $\mathrm{~F}$ & C & & & & & $F$ & & & $\mathrm{~F}$ & & & & $c$ & $R$ & $R$ & $R$ & & - PIR & \\
\hline $26 \mathrm{R}-2,2-3 \mathrm{~cm}$ & $R$ & $\mathrm{~F}$ & $\mathrm{~F}$ & c & & & & & $\mathrm{F}$ & & & $R$ & & $R$ & & $c$ & $\bar{R}$ & \begin{tabular}{l|l}
$R$ & $F$ \\
\end{tabular} & & & - PIM & \\
\hline $26 R, C C$ & \multicolumn{21}{|c|}{ batren } & $?$ \\
\hline $25 R, C c$ & $R$ & $F$ & $R$ & c & & & & & $F$ & & & & & & & $c$ & & $R$ & $R$ & & $\Delta P / M$ & NN $1 / 2$ \\
\hline Core $26 R$ & \multicolumn{21}{|c|}{ barten } & $?$ \\
\hline
\end{tabular}


Table 12 (continued).

\begin{tabular}{|c|c|c|c|c|c|c|c|c|c|c|c|c|c|c|c|c|c|c|c|c|c|c|c|c|c|c|c|c|c|c|c|c|c|c|c|c|c|c|c|c|}
\hline & & & 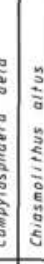 & & & 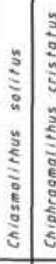 & 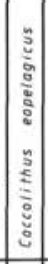 & 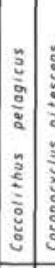 & 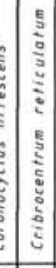 & & 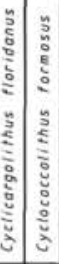 & & 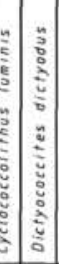 & 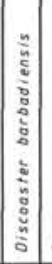 & 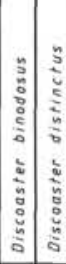 & & 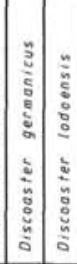 & 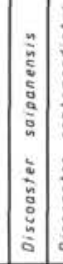 & 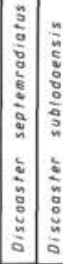 & 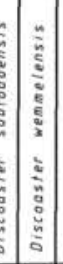 & 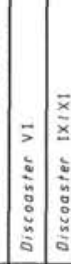 & 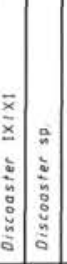 & 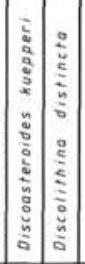 & 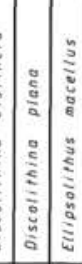 & 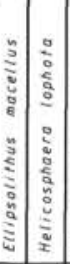 & 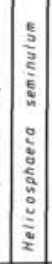 & 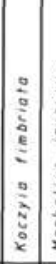 & & 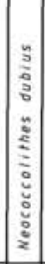 & 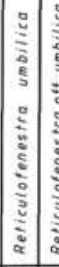 & 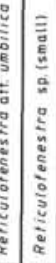 & 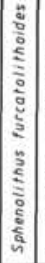 & 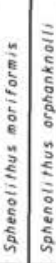 & 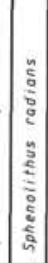 & 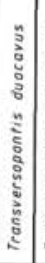 & 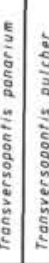 & 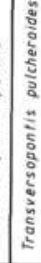 & 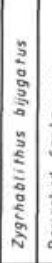 & 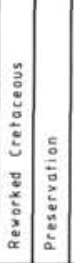 & 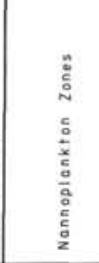 \\
\hline $27 \mathrm{R}-1,120 \mathrm{~cm}$ & & & $\mathrm{R}$ & & & $F$ & & \begin{tabular}{l|l}
$c$ & $R$ \\
\end{tabular} & \begin{tabular}{|l|}
$R$ \\
$R$
\end{tabular} & & c & & & & \begin{tabular}{l|l}
$R$ & $R$ \\
\end{tabular} & & & $\mathrm{R}$ & & & & $R$ & & & & $\mathrm{R}$ & & & $R$ & \begin{tabular}{|l|l|l|}
$R$ & \\
\end{tabular} & & \begin{tabular}{l|l}
$R$ \\
\end{tabular} & $R$ & $\mathrm{R}$ & & $\mathrm{R}$ & & $R$ & \begin{tabular}{|l|l|}
$R$ & $M$ \\
\end{tabular} & $N P 16$ \\
\hline $27 \mathrm{R}-2,16-17 \mathrm{~cm}$ & $R$ & & R & & \begin{tabular}{l|l}
$R$ & \\
\end{tabular} & $\begin{array}{ll} \\
\end{array}$ & & \begin{tabular}{l|l|}
$c$ & \\
\end{tabular} & $R$ & & $R$ & & & & R & & & I & 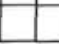 & & 11 & 1 & & & $F$ & & & & & \begin{tabular}{|l|l|l|l} 
& \\
\end{tabular} & $F$ & & $R$ & & & & & & \begin{tabular}{|l|l|}
$R$ & $P$ \\
\end{tabular} & NP 16 \\
\hline$\frac{27 R, c t}{29 R, c t}$ & \multicolumn{39}{|c|}{ b a r r e n } & $?$ \\
\hline 30R,.te & & & R & & & $R$ & & $\mathrm{R}$ & & & & & R & \begin{tabular}{|c|} 
et. \\
\end{tabular} & & & & et: & & & & & & & & & & & & $R$ & $\mathrm{R}$ & & & & & & & & & \multirow{2}{*}{ NP 16} \\
\hline $318 ., c$ & & & & & & & $\mathrm{R}$ & $\mathrm{R}$ & $R$ & & & & & & & & $R$ & \begin{tabular}{|l|l|l|}
$R$ & \\
\end{tabular} & & & & T & & & & & & & & $R$ & $F$ & & & & & & & & 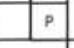 & \\
\hline$\frac{32 R, \mathrm{cC}}{33 R, \mathrm{Cl}}$ & \multicolumn{39}{|c|}{ b a $r$ r e } & ? \\
\hline $34 \mathrm{R}-2,11-12 \mathrm{~cm}$ & & & & & \begin{tabular}{|l|l|}
$R$ & \\
\end{tabular} & $R$ & $R$ & $F$ & & & $\mathrm{R}$ & & \begin{tabular}{|l|}
$\mathrm{R}$ \\
$\mathrm{et}$
\end{tabular} & & $\mathrm{R}$ & & c. & & & & & & & & & $\mathrm{R}$ & & & & $\mathrm{R}$ & $\mathrm{F}$ & & & & & & & $\mathrm{R}$ & p & \multirow{5}{*}{ NP 16} \\
\hline $34 \mathrm{R}, \mathrm{ct}$ & & & & & & & $\mathrm{R}$ & $F$ & & & $R$ & & $F$ & & ct. & & & \begin{tabular}{|l|l} 
& \\
\end{tabular} & & & & 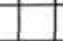 & & & 1 & & & & & $R$ & $\mathrm{~F}$ & & R & & & & & & $p$ & \\
\hline $358-1,30 \mathrm{~cm}$ & & & & & & & & $R$ & $R$ & $\mathrm{~F}$ & \begin{tabular}{l|l}
$F$ & $R$ \\
\end{tabular} & & $F$ & $R$ & & & & \begin{tabular}{l|l}
$F$ \\
\end{tabular} & & & & & & & $\mathrm{R}$ & & & & & $\mathrm{F}$ & c & & & & & & & & PM & \\
\hline 358,66 & & & & & & & & $R$ & & & $\mathrm{R}$ & & & & 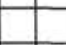 & & & & & & 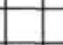 & $R$ & & & & O & & & & $R$ & $F$ & & 2 & & & & & & $p$ & \\
\hline $36 \mathrm{R}-1,60-61 \mathrm{~cm}$ & & \begin{tabular}{r|r}
$R$ & $F$ \\
\end{tabular} & $R$ & & & $F$ & $R$ & c & & \begin{tabular}{|l|l}
$R$ & $F$ \\
\end{tabular} & $\begin{array}{ll}R & C \\
\end{array}$ & & & $R$ & $R$ & & & & & & $F$ & $R$ & $R$ & & $F$ & $F$ & & & $R$ & c & c & & $\mathrm{F}$ & & R & R & & & $P, M$ & \\
\hline $36 \mathrm{R}-2,18-19 \mathrm{~cm}$ & $\mathrm{R}$ & & & & & $R$ & & $F$ & & & & & & & & & & & $R$ & & & & & & & & & & & & \begin{tabular}{l|l}
$R$ & $R$ \\
\end{tabular} & & $\mathrm{R}$ & & & & & $R$ & $p$ & NP 14 \\
\hline $36 \mathrm{R}-2,140-14 \mathrm{~cm}$ & $R$ & & & & & $F$ & & c & & & $F$ & & & $R$ & & & $\mathrm{~F}$ & & & & & $\mathrm{R}$ & \begin{tabular}{|l|l|}
$\because$ & $R$ \\
\end{tabular} & $R$ & \begin{tabular}{|l|l|}
$R$ & $R$ \\
\end{tabular} & $F$ & $R$ & & & & \begin{tabular}{|l|l|}
$R$ & $C$ \\
\end{tabular} & & \begin{tabular}{l|l} 
R \\
\end{tabular} & & & & $R$ & & $p$ & \multirow{10}{*}{ NP 13} \\
\hline $36 \mathrm{R}-3,70-71 \mathrm{~cm}$ & & & & & & c & $R$ & & & & $F$ & & & & $\begin{array}{ll}R \\
\end{array}$ & & $R$ & & $F$ & ct. & & & & & $R$ & & & & 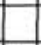 & & \begin{tabular}{l|l}
$R$ & $C$ \\
\end{tabular} & & \begin{tabular}{l|l}
$R$ \\
$R$
\end{tabular} & & & $R$ & & & $p$ & \\
\hline $36 \mathrm{R}-4,57-58 \mathrm{~cm}$ & & & & & & c & $\mathrm{R}$ & & & & c & & & $R$ & \begin{tabular}{l|l}
$R$ & \\
\end{tabular} & & & & $\mathrm{R}$ & $\mathrm{R}$ & & \begin{tabular}{l|l}
$R$ \\
\end{tabular} & $R$ & & $F$ & $\mathrm{R}$ & & & $\mathrm{R}$ & F & \begin{tabular}{l|l} 
\\
\end{tabular} & & a. & & & & & & $P$ & \\
\hline $36 \mathrm{R}, \mathrm{cc}$ & & & & & & $R$ & $\mathrm{R}$ & & & & $\mathrm{F}$ & & & $R$ & & $R$ & R & & $\mathrm{R}$ & & & & & & $\mathrm{R}$ & $\mathrm{R}$ & $\mathrm{F}$ & 8 & & & c & & $\mathrm{R}$ & $R$ & & 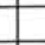 & & & $p$ & \\
\hline $37 \mathrm{R}-2.70-71 \mathrm{CO}$ & $R$ & & & & & $\mathrm{~F}$ & $\mathrm{R}$ & c & & & c & & & & it & & $R$ & & & & & $R$ & \begin{tabular}{|l|l|}
$R$ & $R$ \\
\end{tabular} & $R$ & $R$ & $\mathrm{~F}$ & & & ( & & \begin{tabular}{l|l} 
& $c$ \\
\end{tabular} & & \begin{tabular}{|l|l|}
$R$ \\
$R$
\end{tabular} & & & 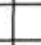 & & $R$ & $p$ & \\
\hline $378, \mathrm{ct}$ & & & & & & $F$ & $\mathrm{R}$ & c & & & $\mathrm{c}$ & & & $R$ & $\mathrm{R}$ & & $F$ & & & & $F$ & $\begin{array}{ll} \\
\end{array}$ & \begin{tabular}{|l|l|}
$R$ & \\
\end{tabular} & \begin{tabular}{|l|l} 
& $R$ \\
\end{tabular} & \begin{tabular}{|l|l|}
$R$ & $R$ \\
\end{tabular} & $F$ & $R$ & & $R$ & & \begin{tabular}{l|l} 
& $c$ \\
\end{tabular} & & \begin{tabular}{l|l}
$R$ & $R$ \\
\end{tabular} & & & $\mathrm{R}$ & & & PIM & \\
\hline $38 \mathrm{R}-6,3-6 \mathrm{Cm}$ & & F & & & & $\mathrm{F}$ & & $c$ & & & c & & & & R & & $R$ & & & & & & \begin{tabular}{|l|l|}
$R$ & $R$ \\
\end{tabular} & \begin{tabular}{|l|l|}
$R$ \\
\end{tabular} & $\mathrm{~F}$ & c & & & $\mathrm{R}$ & & C & & \begin{tabular}{l|l}
$R$ & $R$ \\
\end{tabular} & & & $\mathrm{R}$ & $R$ & & $p$ & \\
\hline $38 \mathrm{R}, \mathrm{tt}$ & & & & & & $R$ & $\mathrm{R}$ & c & & $\mathrm{R}$ & c & & & & R & & $R$ & & & & & (t & $\begin{array}{ll} \\
\end{array}$ & & $\mathrm{R}$ & $\mathrm{F}$ & & & $\mathrm{R}$ & & \begin{tabular}{l|l} 
& $c$ \\
\end{tabular} & & $\mathrm{R}$ & & & $R$ & & & PIM & \\
\hline $39 \mathrm{R}-2,12-13 \mathrm{~cm}$ & $R$ & & & $\mathrm{R}$ & & $R$ & $R$ & $c$ & & & $\mathrm{~F}$ & & & & $\mathrm{R}$ & & R & & & & & $R$ & & & $\mathrm{R}$ & $F$ & $R$ & & $R$ & F & \begin{tabular}{l|l}
$R$ & $C$ \\
\end{tabular} & & \begin{tabular}{l|l}
$R$ & $R$ \\
\end{tabular} & & & $2 \mathrm{R}$ & $\mathrm{R}$ & & PIM & \\
\hline $39 R, c \mathrm{Ce}$ & & & & & & $R$ & & $\mathrm{R}$ & & & $R$ & & & & & & 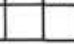 & & & & & 1 & $\mathrm{R}$ & & & & $R$ & & & & $R$ & & $\begin{array}{ll}R \\
\end{array}$ & & & & & & $\mathrm{P}$ & \\
\hline$\frac{40 R, C G}{41 R, C t}$ & \multirow{2}{*}{\multicolumn{39}{|c|}{ b a r r e n }} & \\
\hline $62 R-1,48-69 \mathrm{CB}$ & & & & & & $\mathrm{R}$ & & $R$ & & & $\mathrm{R}$ & $R$ & & & & & & & & & & & & & & & & & & & & & & & & & & & $\mathrm{P}$ & \multirow{7}{*}{ NP 13} \\
\hline${ }_{42 \mathrm{R}, \mathrm{ct}}$ & & & & & R & \begin{tabular}{|l|l} 
\\
\end{tabular} & & c & & & $\mathrm{F}$ & & & & & & R & & & & & $R$ & & & & $F$ & & & & & $c$ & & $\begin{array}{l}R \\
R\end{array}$ & R & & & & & PIM & \\
\hline $43 \mathrm{R}-6,65-66 \mathrm{~cm}$ & & $\mathrm{~F}$ & ? & $R$ & $\mathrm{~F}$ & \begin{tabular}{l|l}
$c$ & $R$ \\
\end{tabular} & $R$ & C & & & & & & $\mathrm{R}$ & \begin{tabular}{l|l}
$\mathrm{R}$ & \\
\end{tabular} & & & & & & & $\mathrm{R}$ & $R$ & & $R$ & $F$ & & & & $\mathrm{~F}$ & \begin{tabular}{|l|l|} 
& \\
\end{tabular} & & \begin{tabular}{l|l}
$R$ & \\
$R$
\end{tabular} & & & & & & PIM & \\
\hline $43 R, 46$ & $R$ & & & & R & \begin{tabular}{|l|l}
$F$ & $R$ \\
\end{tabular} & & $c$ & & & c & & & $R$ & \begin{tabular}{|l|l}
$R$ \\
\end{tabular} & & & & & & & & & & & $F$ & & & $R$ & & $c$ & & $R$ & & & & & & PPM & \\
\hline $4 \angle \mathrm{R}-2,50-51 \mathrm{~cm}$ & & & & $R$ & & \begin{tabular}{|l|l}
$F$ & $R$ \\
\end{tabular} & $\mathrm{R}$ & c & & & c & & & $\begin{array}{ll} \\
\end{array}$ & \begin{tabular}{l|l}
$c t$ & \\
\end{tabular} & & & & & & ct & & & & & $R$ & & & $R$ & F & $A$ & & R & & & & & & P & \\
\hline$\angle 4 \mathrm{R}, c \mathrm{C}$ & & & & & & \begin{tabular}{|l|l}
$R$ & $R$ \\
\end{tabular} & & $F$ & & & $\mathrm{R}$ & & & & & & $R$ & & & & & $R$ & & & $R$ & $R$ & & & & F & $\mathrm{F}$ & & st & & & & & $R$ & $p$ & \\
\hline 45R,,$c \mathrm{c}$ & $R$ & & & & & c & & c & & & $\mathrm{F}$ & & & $R$ & $R$ & & $R$ & & & & & $R$ & $R$ & & & $R$ & & & $R$ & & $F$ & & $R$ & & & $R$ & & & $\mathrm{P}$ & \\
\hline
\end{tabular}




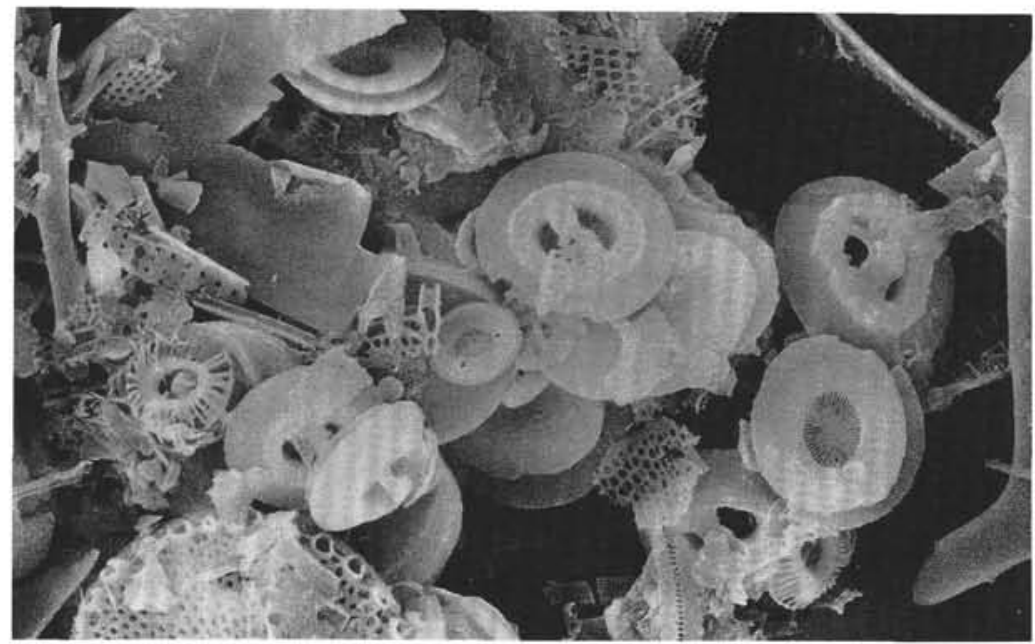

1

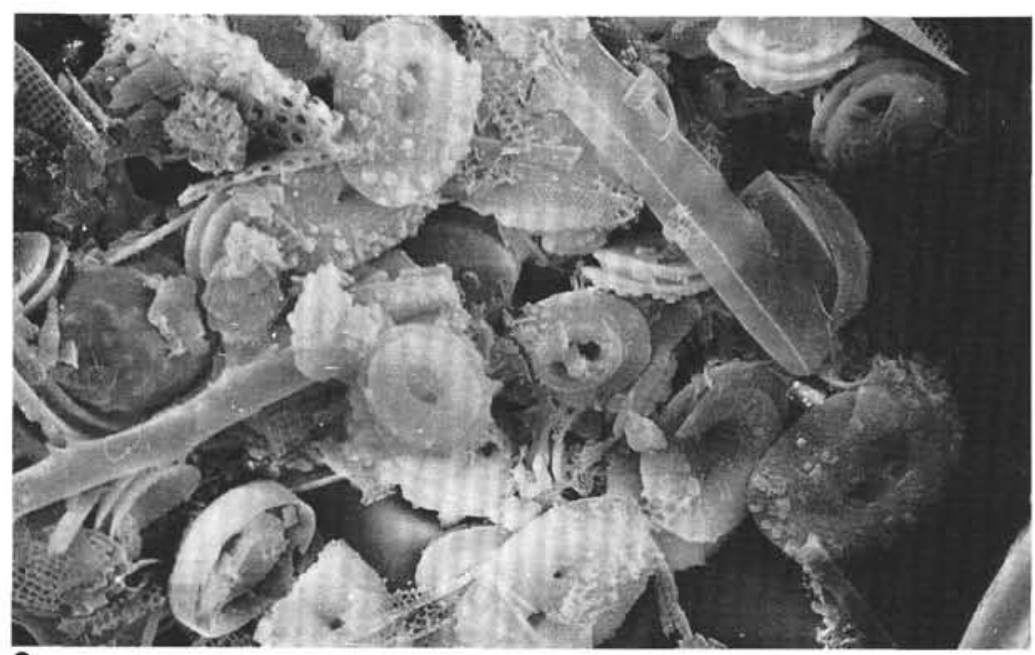

2

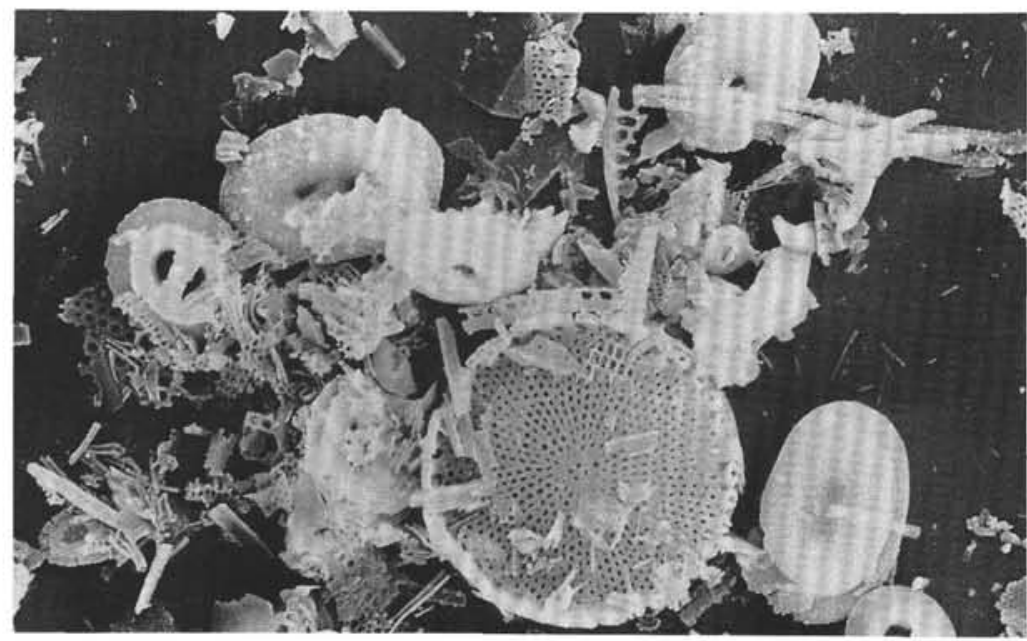

3

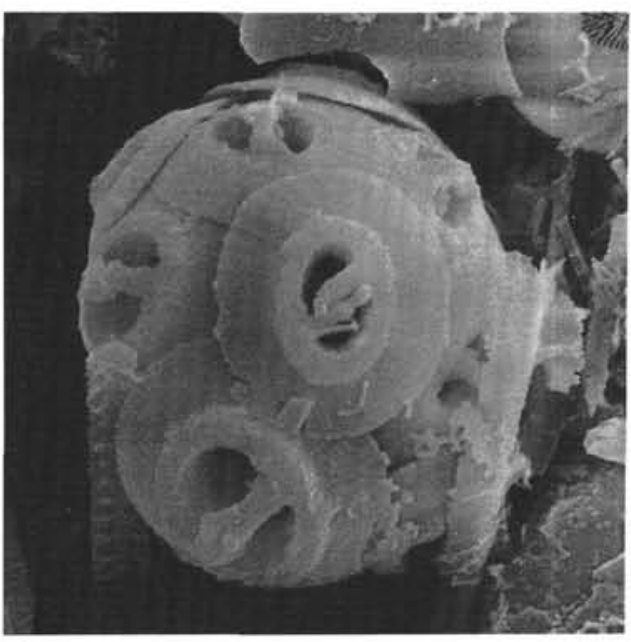

4

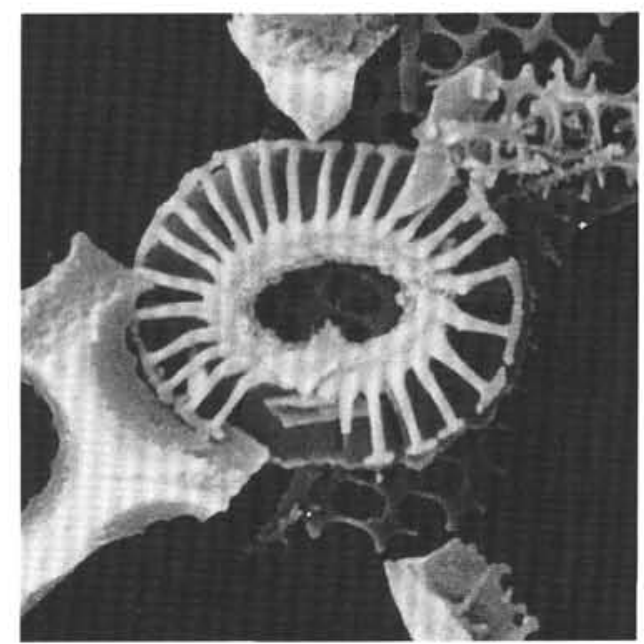

5

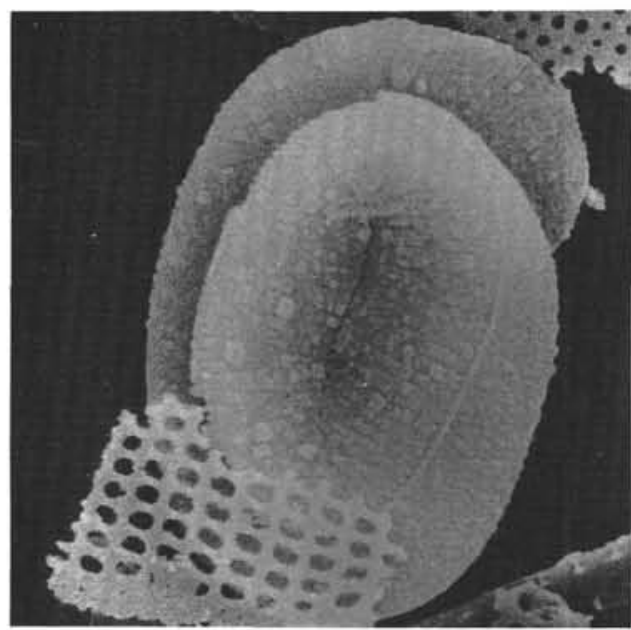

6

Plate 1. Holocene calcareous nannoplankton from a bloom horizon at 112-680B-2H-1, $105-106 \mathrm{~cm}$, in otherwise diatomaceous muds (nannoplankton Zone NN21). 1-3. Different concentrations of the Gephyrocapsa oceanicalHelicosphaera carteri bloom containing Emiliania huxleyi (magnification 3650×, SEM). 4. Complete sphere of Gephyrocapsa oceanica Kamptner, SEM 5650×. 5. Emiliania huxleyi (Lohmann), SEM 12,000×. 6. Helicosphaera carteri (Wallich), SEM 8000×. 


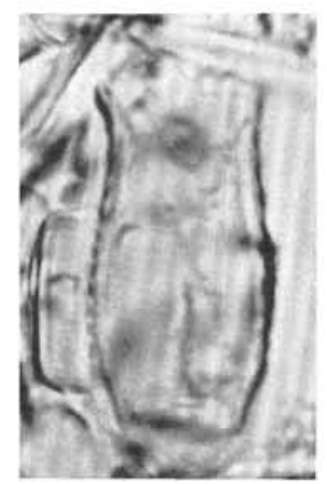

1

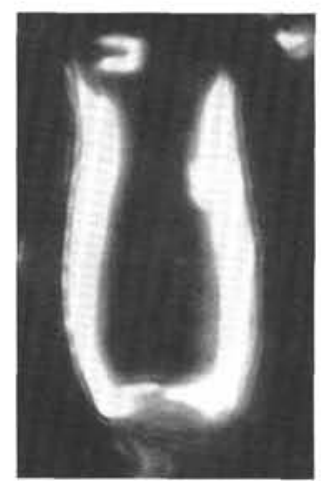

2

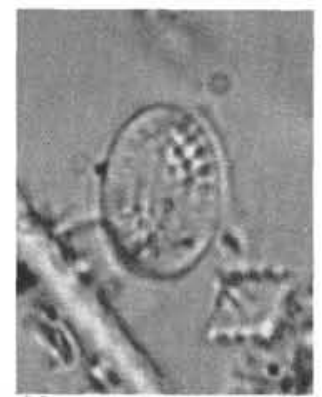

11

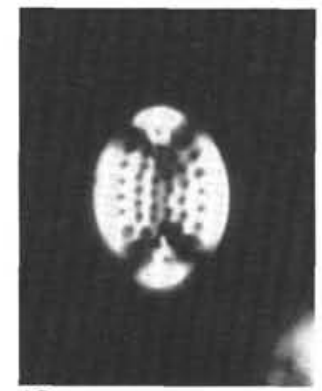

12

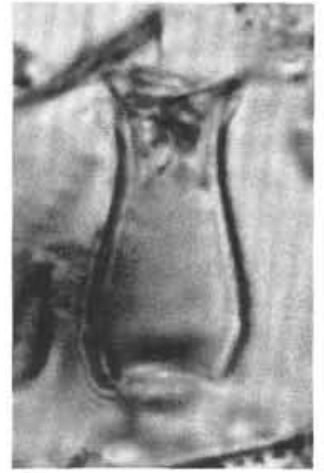

3

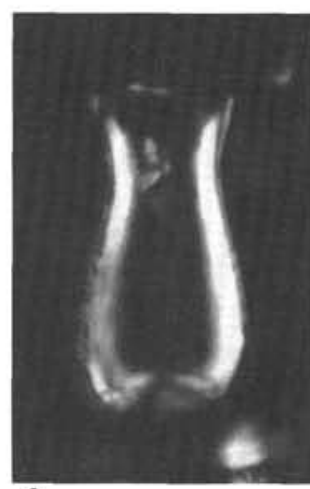

4

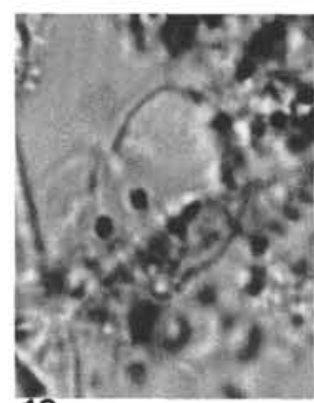

13

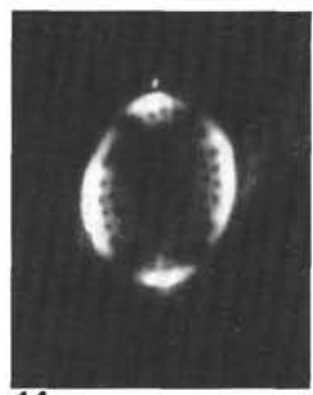

14

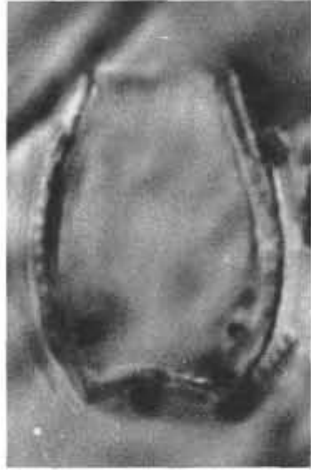

5

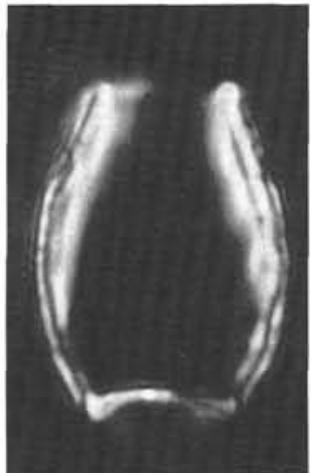

6

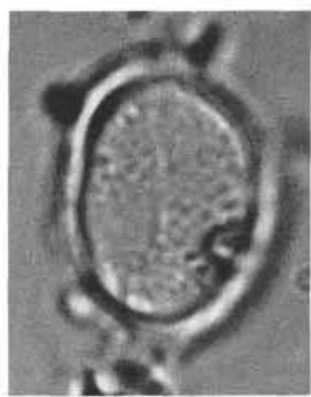

15

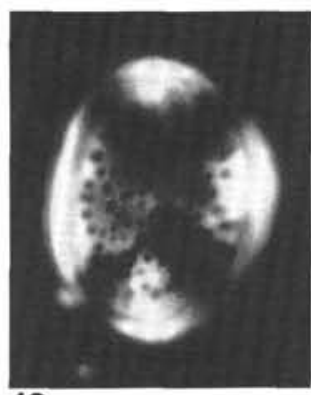

16

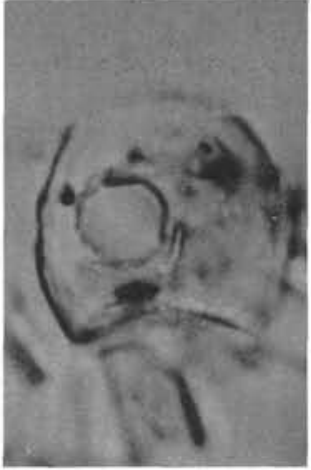

7

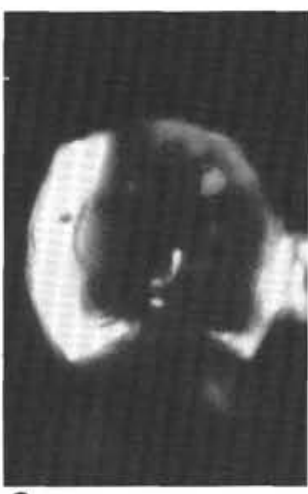

8

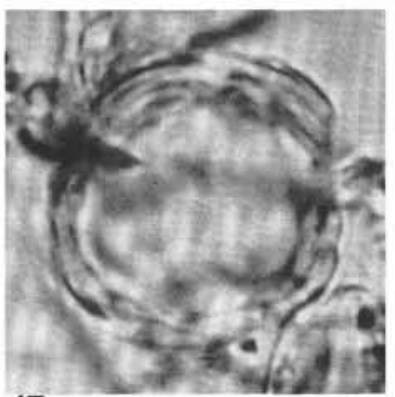

17

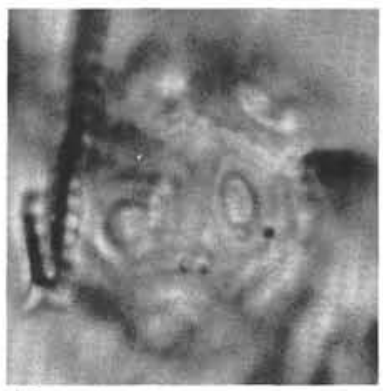

18

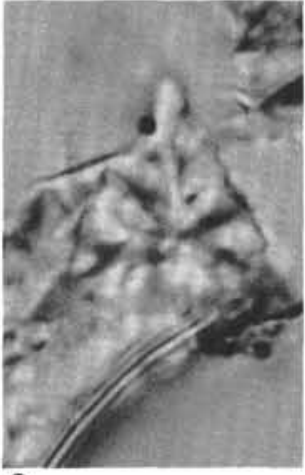

9

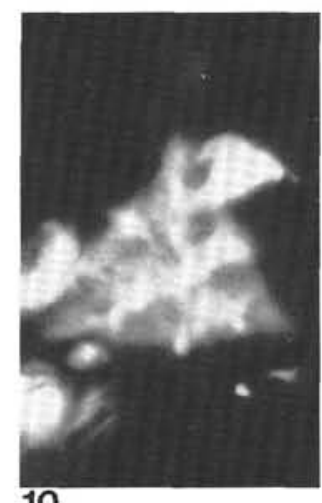

10

Plate 2. Miocene calcareous nannoplankton (All specimens magnified 2000×). 1, 2. Scyphosphaera amphora Deflandre, Sample 112-684A-14X, CC. 3, 4. Scyphosphaera intermedia Deflandre, Sample 112-684A-13X, CC. 5, 6. Scyphosphaera apsteini Lohmann, Sample 112-684A-13X, CC. 7, 8. Scyphosphaera apsteini Lohmann, Sample 112-684A-14X, CC. 9, 10. Lithostromation perdurum Deflandre, Sample 684A-14X, CC. 11, 12. Discolithina multipora (Kamptner ex Deflandre), Sample 112-684A-14X, CC. 13, 14. Discolithina callosa Martini, Sample 112-684A-14X, CC. 15, 16. Scyphosphaera sp. (base), Sample 112-684A-14X, CC. 17, 18. Reticulofenestra pseudoumbilica (Gartner), coccosphere, Sample 112-684A-14X, CC. 19-21. Catinaster coalitus Martini and Bramlette, Sample 112-683A-30X-2, 41-42 cm. 1-18. Nannoplankton Zone NN9. 19-21. Nannoplankton Zone NN8. 